\title{
Revision of the Genera Sphodropoda, Trachymantis and Zopheromantis (Mantodea: Mantidae: Mantinae)
}

\author{
G.A. MilledGe \\ Terrestrial Zoology, Australian Museum, \\ 6 College Street, Sydney NSW 2010, Australia \\ grahamm@austmus.gov.au
}

\begin{abstract}
The genera Sphodropoda Stål, Trachymantis Giglio-Tos and Zopheromantis Tindale are revised. Aspects of their biology are discussed and distributions given. One new species of Sphodropoda, S. lepida, is described. Sphodropoda moesta Giglio-Tos, S. mjobergi Sjöstedt and S. papua are new synonyms of S. tristis (Saussure). Sphodropoda dentifrons Stål is transferred to Trachymantis. S. loripes Tindale is transferred to Zopheromantis. Z. trimaculata Tindale is a new synonym of Z. loripes.
\end{abstract}

MilledGe, G.A., 2005. Revision of the genera Sphodropoda, Trachymantis and Zopheromantis (Mantodea: Mantidae: Mantinae). Records of the Australian Museum 57(2): 191-210.

Sphodropoda Stål, Trachymantis Giglio-Tos and Zopheromantis Tindale are three closely related mantid genera, known only from mainland Australia and, in the case of Sphodropoda, Papua New Guinea, the Solomon Islands and possibly Fiji. All are shrub and tree dwellers, and most of the species inhabit drier regions.

Stål (1871) erected Sphodropoda as a subgenus of Hierodula Burmeister and included a single species, $H$. (Sphodropoda) tristis (Saussure). Westwood (1889) elevated Sphodropoda to generic level. Trachymantis was erected by Giglio-Tos (1917) for T. obesa Giglio-Tos and Zopheromantis by Tindale (1924) for Z trimaculata Tindale. Beier (1935) incorrectly synonymized Zopheromantis with Hierodula without giving reasons. Zopheromantis is recognized here as a valid genus.

\section{Materials and methods}

Methods and terminology follow Milledge (1990, 1997). The following abbreviations are used for male genitalia: $a p r$, apical process of left phallomere; $d p r$, distal process of ventral phallomere; $p a$, phalloid apophysis. Measure- ments are in $\mathrm{mm}$ and range from the smallest specimen examined to the largest, except where an insufficient range of material was available, when single measurements are given. Abbreviations used for institutions where material is held are as follows: AM, Australian Museum, Sydney; ANIC, Australian National Insect Collection, Canberra; BMNH, The Natural History Museum, London; NHRM, Swedish Museum of Natural History, Stockholm; NMV, Museum Victoria, Melbourne; SAM, South Australian Museum, Adelaide; WAM, Western Australian Museum, Perth; ZMHU, Zoologisches Museum der HumboltUniversitat, Berlin.

\section{Relationships}

These three genera appear to form a closely related group, sharing a number of characters including well-developed preacetabular spine, facial shield as wide as high, denticules between teeth on outer margins of fore femora and bifurcate distal process in the male genitalia. Beier (1964) placed Sphodropoda and Trachymantis in his Miomantini, a tribe 

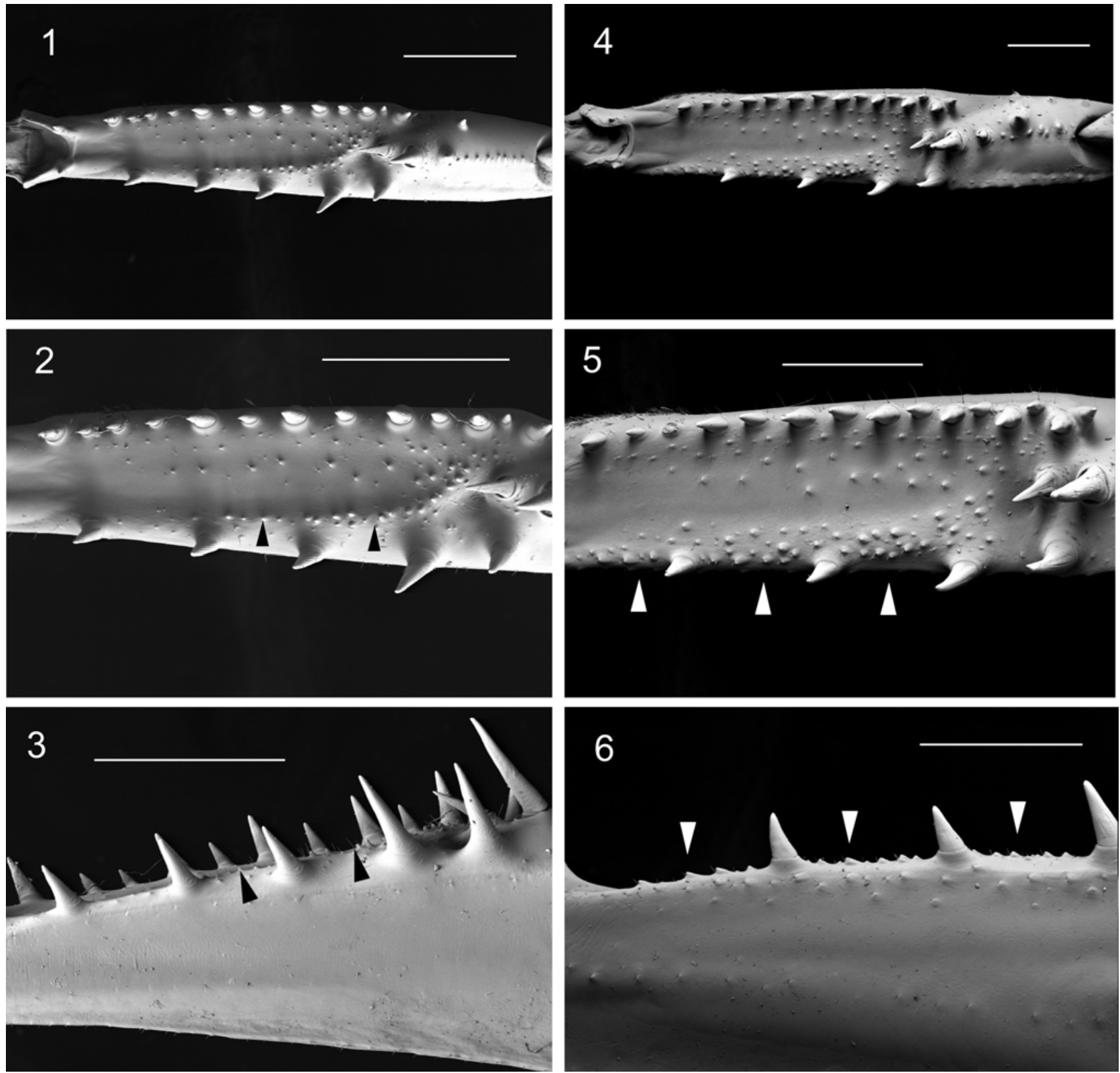

Figs. 1-6. Right fore femur, females, arrows indicate denticles. (1) Iris sp., ventral view; (2) same, ventral view, distal two thirds; (3) same retrolateral view, distal two thirds. (4) Sphodropoda quinquedens, ventral view; (5) same, ventral view, distal two thirds; (6) same retrolateral view, distal two thirds. Scales $=2 \mathrm{~mm}$

sharing only the single synapomorphy of denticules between the outer spines of the fore femora. He obviously had not examined specimens of Zopheromantis as he considered it to be a synonym of Hierodula (Mantini), which lacks this feature. There is some doubt as to whether the Miomantini is monophyletic, as the genera within it display a wide variety of forms. The denticules between the outer spines in the three genera considered here are really only small tubercules, and could be interpreted as a manifestation of the relatively tuberculate cuticle they possess. I have examined specimens of the European genus Iris Saussure, which Beier also included in his Miomantini. The pattern of denticles (Figs. $1-3)$ is different from that found in the genera considered here (Figs. 4-6). In fact, the denticles are not between the outer spines but on the ventral surface of the femur. The original authors (Stål, Giglio-Tos and Tindale) considered the genera revised here to be related to Hierodula. Although this seems more likely than Beier's grouping, as noted elsewhere (Milledge, 1997), further work is required on the mantid fauna of other parts of the world before the relationships of the Australian fauna can be fully understood.

\section{Sphodropoda Stål}

Sphodropoda Stål, 1871: 399. Type species Sphodropoda tristis Saussure, by original designation.

Diagnosis. Head about as high as wide, frontal shield without dorsal extensions; preacetabular spine strong; inner face of first tarsal segment partly or wholly black, ventral face of fore femur tuberculate, especially toward outer margin; both sexes macropterous (some females slightly brachypterous), ventral face of costal area of tegmen at least 
partly red. Can be distinguished from Trachymantis by the lack of a tooth on the apex of the frontal shield and from Zopheromantis by the hind femur being only about half the length of the abdomen.

Description. Small to moderately large, body robust, male macropterous, female macropterous to slightly brachypterous. Head about as wide as high, not significantly compressed anteroposteriorly, apical margin gently arched; eyes rounded, not particularly prominent; frontal shield slightly wider than high, flat, with distinct ridge laterally and apically but not produced into a tooth at apex.

Pronotum moderately elongate, supracoxal expansion slight to distinct, dorsal surface finely to moderately coarsely granulate, margins finely denticulate, ventral surface with preacetabular spine prominent. Fore coxa as long as or longer than metazone of pronotum, often with distinctive pattern on inner face and a number of prominent tubercles on anterior margin. Fore femur finely tuberculate on ventral surface, particularly toward outer margin; with four discoidal spines, relative length from longest to shortest 32-1-4; with four outer and 15 inner spines, claw groove situated at about a third the total distance from base. Inner face of tarsus largely black.

Tegmen with costal area opaque, partially red beneath; discoidal area entirely opaque to mostly hyaline. Hind wing with costal and discoidal area pigmented, anal area largely hyaline. Mid and hind legs relatively short, hind femur about half the length of abdomen. Abdomen moderately elongate, cerci short, slender and cylindrical. Male genitalia with $d p r$ bifurcate.

Notes. All the species in this genus have relatively short legs, a feature that appears to be associated with the behavioural adaptation of depressing the body against the substrate when threatened. This behaviour has been observed in three of the species recognized here (S. tristis, $S$. quinquedens and $S$. viridis), the behaviour of the other (S. lepida) has not been observed. If the substrate is a branch or twig this behaviour includes moving to the side of the branch facing away from the threat. Similar behaviour appears to have evolved independently in other genera of Mantidae, e.g., Tarachodula (Preston-Mafham 1990, plate 33) and Galepsus (Hevers \& Liske 1991, plate 21).

\section{Key to species of Sphodropoda}

1 Internal face of fore coxa with 5-6 transverse white bands anteriorly (Fig. 15) S. quinquedens Internal face of fore coxa lacking bands 2

2 Anterior margin of fore coxa internally with six to seven whitish tubercles (Fig. 12) S. tristis

Anterior margin of fore coxa without such tubercles... 3

3 Major veins of discoidal area of tegmina uniformly green S. viridis Major veins of discoidal area of tegmina flushed reddish brown S. lepida

\section{Sphodropoda tristis (Saussure)}

Figs. 7-8, 11-13, 17, 42

Mantis tristis Saussure, 1871: 93.

Hierodula (Sphodropoda) tristis (Saussure).-Stål, 1871: 399. Sphodropoda tristis (Saussure).-Westwood, 1889: 13. Sphodropoda moesta Giglio-Tos, 1911: 20; new synonym. Sphodropoda mjobergi Sjöstedt, 1918: 25; new synonym. Sphodropoda papua Beier, 1965: 489-90; new synonym.

Type material examined. Syntype female of Sphodropoda moesta, Cape York, Daemel, cat. no. 3883 (ZMHU). Syntype male and syntype female of Sphodropoda mjobergi, Kimberley district, N.W. Australia, Mjöberg (NHRM).

Other specimens examined. Queensland. 10 , Armstrong Creek crossing, $13 \mathrm{~km}$ NNW of Guthalungra, 26 Jan 1982, M.S. \& B.J. Moulds. 1 , , Biggenden Bluff, Mt. Walsh National Park, 10 Jan 1984, D. Rugg. 1 o, 1 क , $7 \mathrm{~km} \mathrm{~S}$ of Biggenden, Mt. Walsh National Park, 9-12 Apr 1971, H. Frauca. 5 q , Bluff Range, near Biggenden, 2-12 May 1971, H. Frauca. 2 juv, Bluff Range, 8 km S of Biggenden, 9 Jan 1971, H. Frauca. $19,20 \mathrm{~km}$ NE of Bundaberg, Apr 1971, H. Frauca. $10^{\dagger}$, Byfield, 10 May 1955, Common \& Norris. 20,1 으, Carnarvon National Park (Tourist Lodge), $25^{\circ} 05^{\prime} \mathrm{S} 148^{\circ} 15^{\prime} \mathrm{E}, 27$ \& 29 Apr 1979, K.H.L. Key. 1 đ , Clermont, 15 Feb 1975, R.A. Farrow. 30 , 7 km SSW of Clermont, 2 Apr 1977, R.C. Lewis. 19 , 1 juv, near Clohesy River $12 \mathrm{~km} \mathrm{SW}$ of Kuranda, 7 Feb $1988,16^{\circ} 54^{\prime}$ ' $145^{\circ} 34^{\prime}$ E, D.C.F. Rentz. 1 juv, $52 \mathrm{~km}$ SE of Cloncurry, 25 Aug 1960, M.J.D. White. 1 juv, Desailly Creek, $10 \mathrm{~km} \mathrm{NW}$ of Mt.
Carbine, $16^{\circ} 30^{\prime} \mathrm{S} 144^{\circ} 55^{\prime} \mathrm{E}, 19-21$ May 1981, D.C.F. Rentz. 1 o 1 juv, $8 \mathrm{~km} \mathrm{~W}$ of Dimbulah, $17^{\circ} 09^{\prime} \mathrm{S} 145^{\circ} 02^{\prime} \mathrm{E}, 22$ Mar 1988, D.C.F. Rentz. 10 , $42 \mathrm{~km} \mathrm{~N}$ of Emerald, 20 Apr 1955, Norris \& Common. 1 , , Forty Mile Scrub, $55 \mathrm{~km} \mathrm{SSW}$ of Mt. Garnet, $18^{\circ} 06^{\prime} \mathrm{S} 144^{\circ} 50^{\prime} \mathrm{E}, 8$ Dec 1985 , J. Balderson. 10, $3 \mathrm{~km} \mathrm{~N}$ of Greenvale HS, W of Ingham, 5 Apr 1962, K.H.L. Key \& E.L. Corby. 1 juv, Isla Gorge Lookout, Isla Gorge National Park, SSW of Theodore, $25^{\circ} 10^{\prime} \mathrm{S} 150^{\circ} 00^{\prime} \mathrm{E}, 21 \mathrm{Apr} 1982$, D.C.F. Rentz. 10 , 3 km SE of Mary Kathleen, 21 Apr 1962, K.H.L. Key \& E.L. Corby. 1 to, Moondoo, 26 Feb 1963, A.L. Dyce \& M.D. Murray. 1 juv, 10 km SE of Mt. Carbine, 16 $6^{\circ} 37^{\prime} \mathrm{S} 145^{\circ} 12^{\prime} \mathrm{E}, 24$ Nov 1981, J. Balderson. 1 juv, 17 km WSW of Mt. Faulkner, Clermont district, 7 Jan 1965, M.J.D. White. 1 o , Mt. Larcom, 18 Apr 1955, Norris \& Common. $20^{\dagger}$, Running River, $22 \mathrm{~km} \mathrm{~W}$ of Paluma, 11 Feb 1971, J.G. Brooks. $1 \mathrm{o}^{\hat{\alpha}}$, near Poona Lake, Cooloola National Park, $25^{\circ} 58^{\prime} \mathrm{S} 153^{\circ} 07^{\prime} \mathrm{E}, 4$ Apr 1978, D.C.F \& B.G.F. Rentz. 1 \% $1 \mathrm{~km} \mathrm{~N}$ of Rounded Hill, near Cooktown, $15^{\circ} 17^{\prime} \mathrm{S}$ $145^{\circ} 13^{\prime}$ E, 5-7 May 1981, D.C.F. Rentz. 1 o , $23 \mathrm{~km}$ NNE of Taroom, 29 Mar 1977, R.C. Lewis. $10^{\circ}, 9 \mathrm{~km}$ WNW of Taroom, $25^{\circ} 34^{\prime} \mathrm{S} 149^{\circ} 45^{\prime} \mathrm{E}$, 1 Feb 1981, D.C.F. Rentz \& D.T. Gwynne. 1 juv, 7 km E of Toowoomba, 2 Jan 1956, M.J.D. White. 10 , Townsville, 7 Jan 1968, P. Ferrar. 10 , Townsville, 31 Dec 1967, P. Ferrar. 1 \%, Watalgan Range, near Bundaberg, 3 Jul 1971, H. Frauca. $1 \%$, Watalgan Range, S of Rosedale, Mar 1971, H. Frauca. 10, Waverley Creek, Bruce Highway, $10 \mathrm{~km} \mathrm{~S}$ of St. Lawrence turnoff, 27 Jan 1988, M.S. \& B.J. Moulds (All ANIC). 1 \%, Augathella, $25^{\circ} 48^{\prime} \mathrm{S} 146^{\circ} 35^{\prime} \mathrm{E}, 18$ Jan 1993, G. Milledge. 19,16 $\mathrm{km}$ ESE of Burke \& Wills Junction, $19^{\circ} 17^{\prime} \mathrm{S} 140^{\circ} 29^{\prime} \mathrm{E}, 15 \mathrm{Jan} 1993, \mathrm{G}$. Milledge. $10^{\star}, 291 \mathrm{~km}$ NNE of Collins Weir, W of Atherton, $17^{\circ} 15^{\prime} \mathrm{S}$ $145^{\circ} 17^{\prime} \mathrm{E}, 10 \mathrm{Feb} 1989$, G. Milledge. $1 \mathrm{o}^{\hat{\alpha}}, 8 \mathrm{~km}$ E of Emuford, $30 \mathrm{Dec}$ 1989, M.S. \& B.J. Moulds. 5 \% , Georgetown, 12-14 Apr 1991, G. Milledge. $1 \delta^{\hat{x}}$, Georgetown, 16 Apr 1991, G. Milledge. $1 \delta^{\hat{\sigma}}, 12 \mathrm{~km}$ E of Georgetown, 12 Apr 1991, G. Milledge. 1 9, 6 km S of Normanton, 

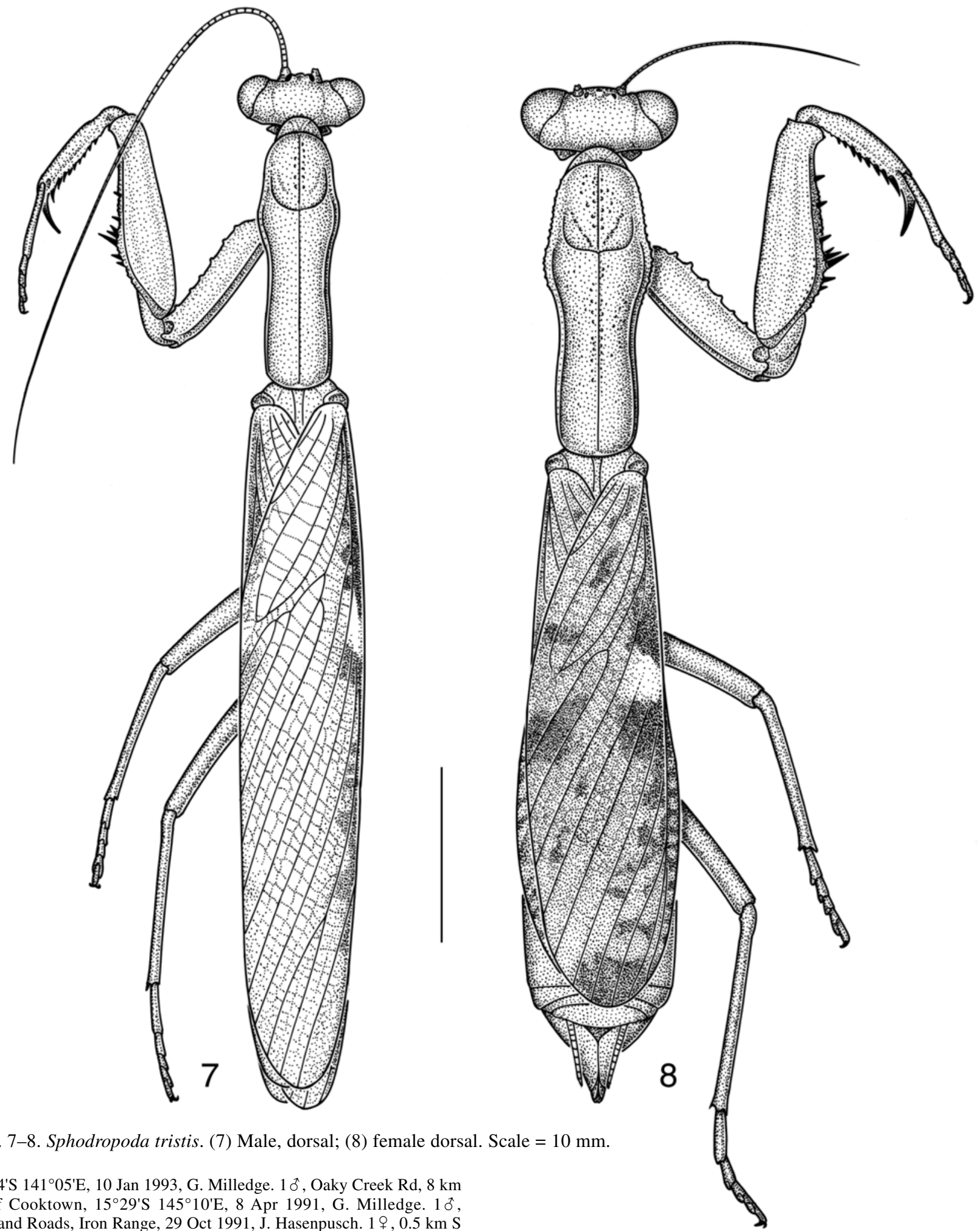

Figs. 7-8. Sphodropoda tristis. (7) Male, dorsal; (8) female dorsal. Scale $=10 \mathrm{~mm}$.

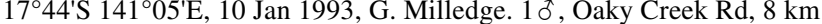
W of Cooktown, $15^{\circ} 29^{\prime} \mathrm{S} 145^{\circ} 10^{\prime} \mathrm{E}, 8$ Apr 1991, G. Milledge. $10^{\star}$, Portland Roads, Iron Range, 29 Oct 1991, J. Hasenpusch. 1 ㅇ, $0.5 \mathrm{~km} \mathrm{~S}$ of Wills Creek, $9.5 \mathrm{~km} \mathrm{NE}$ of Normanton, $17^{\circ} 38^{\prime} \mathrm{S} 141^{\circ} 09^{\prime} \mathrm{E}$, 11 Jan 1993, G. Milledge (all NMV).

New South Wales. 1 juv, $29 \mathrm{~km}$ ENE of Coonabarabran, $31^{\circ} 08^{\prime} \mathrm{S}$ $149^{\circ} 33^{\prime} E, 25$ Nov 1983, D.C.F. Rentz \& M.S. Harvey. 1 ㅇ, Dungay Creek, $13 \mathrm{~km} \mathrm{~W}$ of Kempsey, I.H. Parberry. 1 juv, $5 \mathrm{~km}$ SE of Merrygoen, 18 Jan 1961, M.J. D.White. $1 \delta^{\dagger}, 15$ km WNW of Monia Gap, 2 Feb 1964 , M.J.D. White. 1 juv, $10 \mathrm{~km} \mathrm{~W}$ of Temora, 12 Jan 1955, M.J.D. White (all ANIC). 19 , Clarence River, Mr Wilcox (NMV).

Northern Territory. 1 \%, 43 km SE of Adelaide River, 4 Nov 1966, A. \& R. Mesa. 20 , Barrow Creek Telegraph Station, 20 Mar 1955, K.H.L. Key. 1 juv, Berrimah, 10 Mar 1972, J.C. Wombey. 19,38 km ENE of Birrindudu HS, $18^{\circ} 15^{\prime}$ S $129^{\circ} 45^{\prime} E, 11$ Jul 1969, C. Simpson. 1 juv, Blackfellows Station to Burnside, 2-3 Apr 1929, T.G. Campbell. 1 9, Borroloola, McArthur River, 16 Jun 1929, T.G. Campbell. $1 \delta^{\top}, 22 \mathrm{~km}$ WSW of Borroloola, $16^{\circ} 08^{\prime} \mathrm{S}$ $136^{\circ} 06 \mathrm{E}, 16$ Apr 1976, Key \& Balderson. $10^{\star}, 36 \mathrm{~km} \mathrm{SW}$ of Borroloola, $16^{\circ} 19^{\prime} \mathrm{S} 136^{\circ} 05^{\prime} \mathrm{E}, 4 \mathrm{Nov} 1975$, M.S. Upton. $10^{\circ}, 46 \mathrm{~km}$ SSW of Borroloola, $16^{\circ} 28^{\prime} \mathrm{S} 136^{\circ} 09^{\prime} \mathrm{E}, 28$ Oct 1975, M.S. Upton. 1 juv, Caiman Creek, Coburg Peninsula, $11^{\circ} 14^{\prime} \mathrm{S} 132^{\circ} 12^{\prime} \mathrm{E}, 13$ Feb 1977, R.C. Lewis. 1 9 , Caranbirini Waterhole, $33 \mathrm{~km} \mathrm{SW}$ of Borroloola, $16^{\circ} 16^{\prime} \mathrm{S} 136^{\circ} 05^{\prime} \mathrm{E}, 21 \mathrm{Apr} 1976$, Key \& Balderson. 1 juv, $7 \mathrm{~km} \mathrm{SW}$ of Coolibah HS, 15 $34^{\circ} \mathrm{S} 30^{\circ} 54^{\prime} \mathrm{E}, 28$ Jun 1968, M. Mendum. 1 , , Darwin, 25 Apr 1972, E.C. Abbey. 1 के, 8 km NNW of Elliott, $17^{\circ} 29^{\prime}$ S $133^{\circ} 30^{\prime}$ E, 14 Oct 1972, M.S. Upton. 1 \% , Howard Springs, 30 Dec 1986, M.S. \& B.J. Moulds. 10, Humpty Doo, 29-30 Jan 1939, E.B. Boerema. 10, Mataranka, 26 Mar 1955, K.H.L. Key. 1 ㅇ, McArthur 

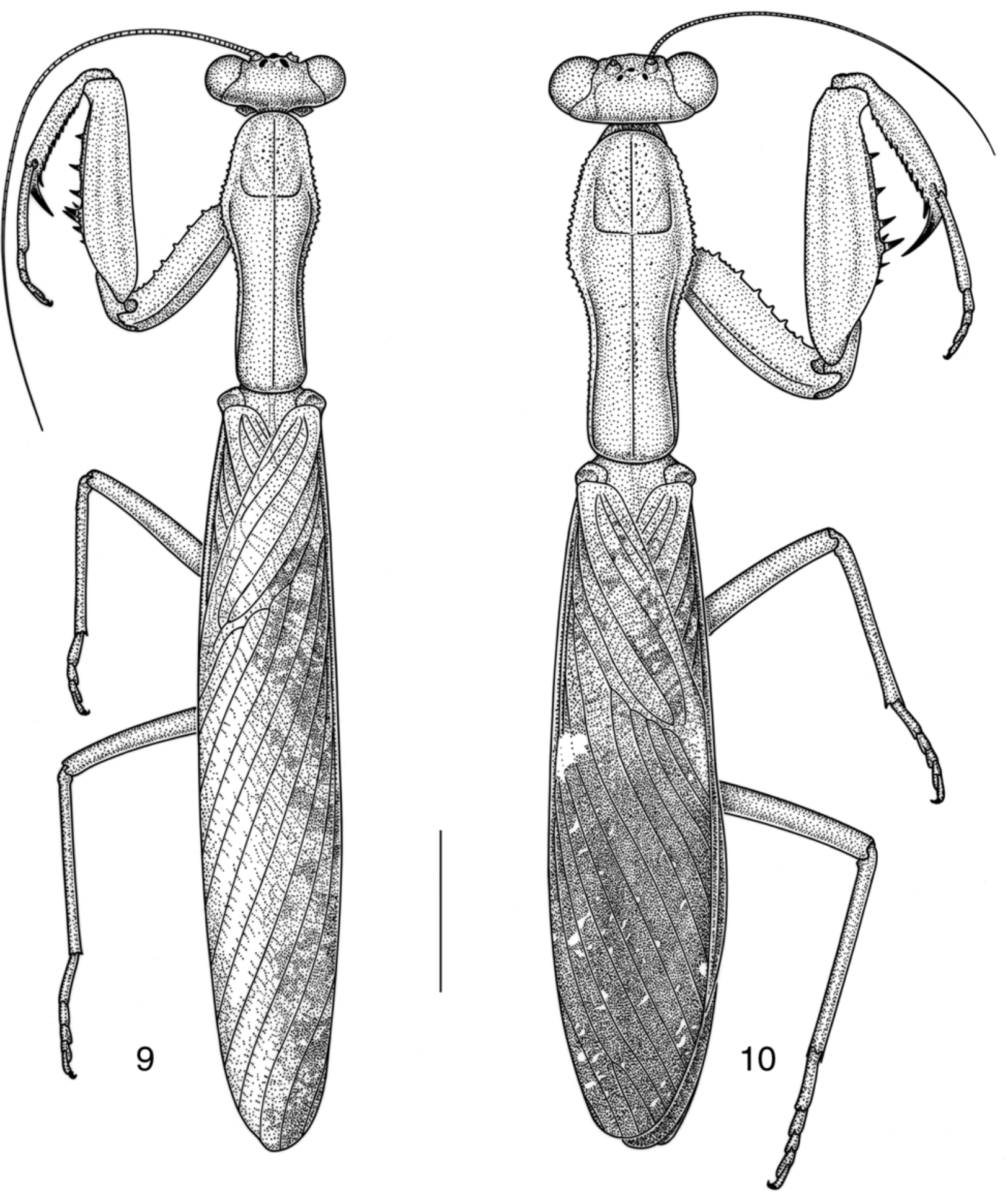

Figs. 9-10. Sphodropoda quinquedens. (9) Male, dorsal; (10) female dorsal. Scale = $10 \mathrm{~mm}$.

River HS, $80 \mathrm{~km} \mathrm{SW}$ of Borroloola, 16 $39^{\circ} \mathrm{S} 135^{\circ} 51^{\prime} \mathrm{E}, 13$ May 1973, M.S. Upton \& J.E. Feehan. $19,16 \mathrm{~km}$ WSW of McArthur River HS, $16^{\circ} 45^{\prime}$ S $135^{\circ} 44^{\prime} \mathrm{E}, 13$ May 1975, Balderson \& Freeman. $10^{\star}, 15 \mathrm{~km}$ E of Mt. Cahill, $12^{\circ} 52^{\prime} \mathrm{S} 132^{\circ} 50^{\prime} \mathrm{E}, 7$ Mar 1973, K.H.L. Key. $10^{\dagger}$, October Creek, Carpentaria Hwy, $180 \mathrm{~km}$ E of Daly Waters, 11 Jan 1986, M.S. \& B.J. Moulds. 10ิ, Plenty Hwy, $268 \mathrm{~km}$ ENE of Alice Springs, $22^{\circ} 47^{\prime} \mathrm{S} 136^{\circ} 18^{\prime} \mathrm{E}, 14$ Oct 1978 ,

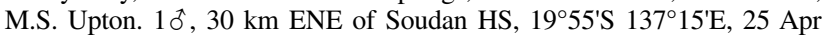
1976, Key \& Balderson. 10े, Standley Chasm, $43 \mathrm{~km} \mathrm{~W}$ of Alice Springs, 9 Feb 1966, Britton, Upton \& McInnes. 10ิ, Stuart Hwy, $58 \mathrm{~km} \mathrm{NW}$ of Alice Springs, $23^{\circ} 11^{\prime} \mathrm{S} 133^{\circ} 44^{\prime} \mathrm{E}, 28$ Oct 1988, D.C.F. Rentz. 1 juv, Tanami Borehole, $19^{\circ} 59^{\prime} \mathrm{S} 129^{\circ} 42^{\prime} \mathrm{E}$, Jul-Sep 1971, J. Hodgson. $20^{\prime}$, Tindal, 14 $31^{\circ} \mathrm{S}$

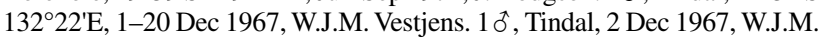
Vestjens. 10, $13 \mathrm{~km} \mathrm{~W}$ of Top Springs, 24 Oct 1965, Blackith \& Mesa. 10ิ,
Uluru Motel, Ayers Rock, $25^{\circ} 21^{\prime}$ S $131^{\circ} 03^{\prime} \mathrm{E}, 4$ Nov 1980, K.H.L. Key (all

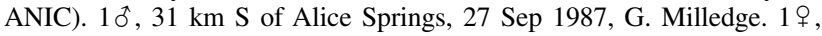
Darwin, Jul-Aug 1912, Prof Spencer. 19 , Uluru Camp Site, Horn Centenary Expedition, $25^{\circ} 23^{\prime} 10^{\prime \prime S} 131^{\circ} 00^{\prime} 46 " \mathrm{E}, 24$ Oct 1994, G. Milledge, 1 웅, Watarrka National Park, Mar 1995, G. Milledge (all NMV).

South Australia. $30^{\dagger}, 8.5 \mathrm{~km}$ WSW of Calperum HS, $34^{\circ} 05^{\prime} \mathrm{S} 140^{\circ} 38^{\prime} \mathrm{E}$, 2 Mar 1995, Cardale, Colloff \& Pullen (ANIC).

Victoria. 19 , Inglewood. $1 \widehat{0}$, Mallee District, 3 Mar 1914, C. French. $10^{\dagger}$, Mallee District. $1 \circ, 22.3 \mathrm{~km} \mathrm{~N}$ of Millewa South Bore, $34^{\circ} 35^{\prime} \mathrm{S}$ $141^{\circ} 03^{\prime} \mathrm{E}, 17-21 \mathrm{Feb} 1987, \mathrm{G}$. Milledge. $19,16.8 \mathrm{~km} \mathrm{SSW}$ of Murrayville, $35^{\circ} 25^{\prime} \mathrm{S} 141^{\circ} 09^{\prime} \mathrm{E}, 23 \mathrm{Feb} 1986, \mathrm{G}$. Milledge. 1 \% , Wyperfield National Park, 3 Mar 1964, H.E. Tarr (all NMV). 

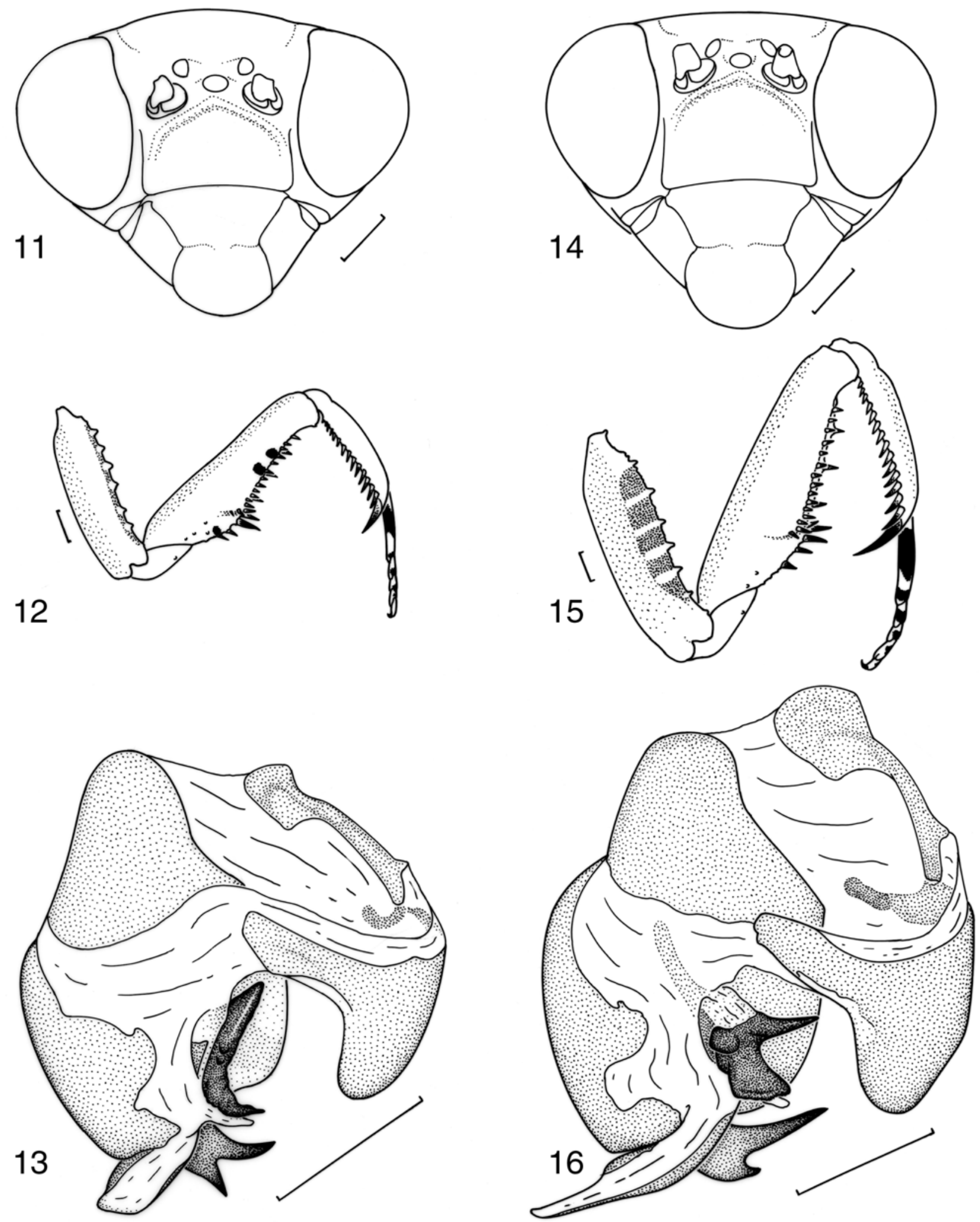

Figs. 11-16. Sphodropoda spp. (11) S. tristis, female head, anterior view; (12) same, fore femur, internal view; (13) same, male genitalia, dorsal view. (14) S. quinquedens, female head, anterior view; (15) same, fore leg, internal view; (16) same, male genitalia, dorsal view. Scales $=2 \mathrm{~mm}$.

Western Australia. 1 ㅇ, Balgo Hills, 13 Oct 1985, M. Golding. 3 ô, 38 km WNW of Balladonia Motel, 22 Feb 1980, D.C.F. 7 B.G.F. Rentz. 1 ț, Brogo Hill, $160 \mathrm{~km} \mathrm{~S}$ of Halls Creek, 10 Sep 1985, M. Golding. $10,42 \mathrm{~km}$ ESE of Broome, 16 Apr 1963, L.J. Chinnick. 10, $145 \mathrm{~km}$ ESE of Broome, $18^{\circ} 55^{\prime}$ S $123^{\circ} 27^{\prime}$ E, 8 Aug 1976, I.F.B. Common. 1 , $186 \mathrm{~km}$ ESE of Broome, $1^{\circ} 53^{\prime} \mathrm{S} 123^{\circ} 43^{\prime} \mathrm{E}, 11$ Aug 1976, I.F.B. Common.

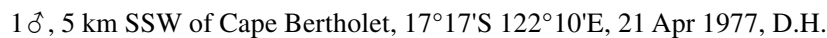
Colless. $10^{\top}, 8 \mathrm{~km} \mathrm{~S}$ of Cape Bertholet, $17^{\circ} 19^{\prime} \mathrm{S} 122^{\circ} 10^{\prime} \mathrm{E}, 16 \mathrm{Apr} 1977$, D.H. Colless. 19 , Halls Creek, 29 Sep 1953, Brittan. 10 , Kimberley Research Station, via Wyndham, 15 Aug 1955, E.C.B. Langfield. 10, Kimberley Research Station, via Wyndham, 28 Dec 1956, E.C.B. Langfield. 1 오 Kimberley Research Station, 21-22 Apr 1958, L.J. \& 

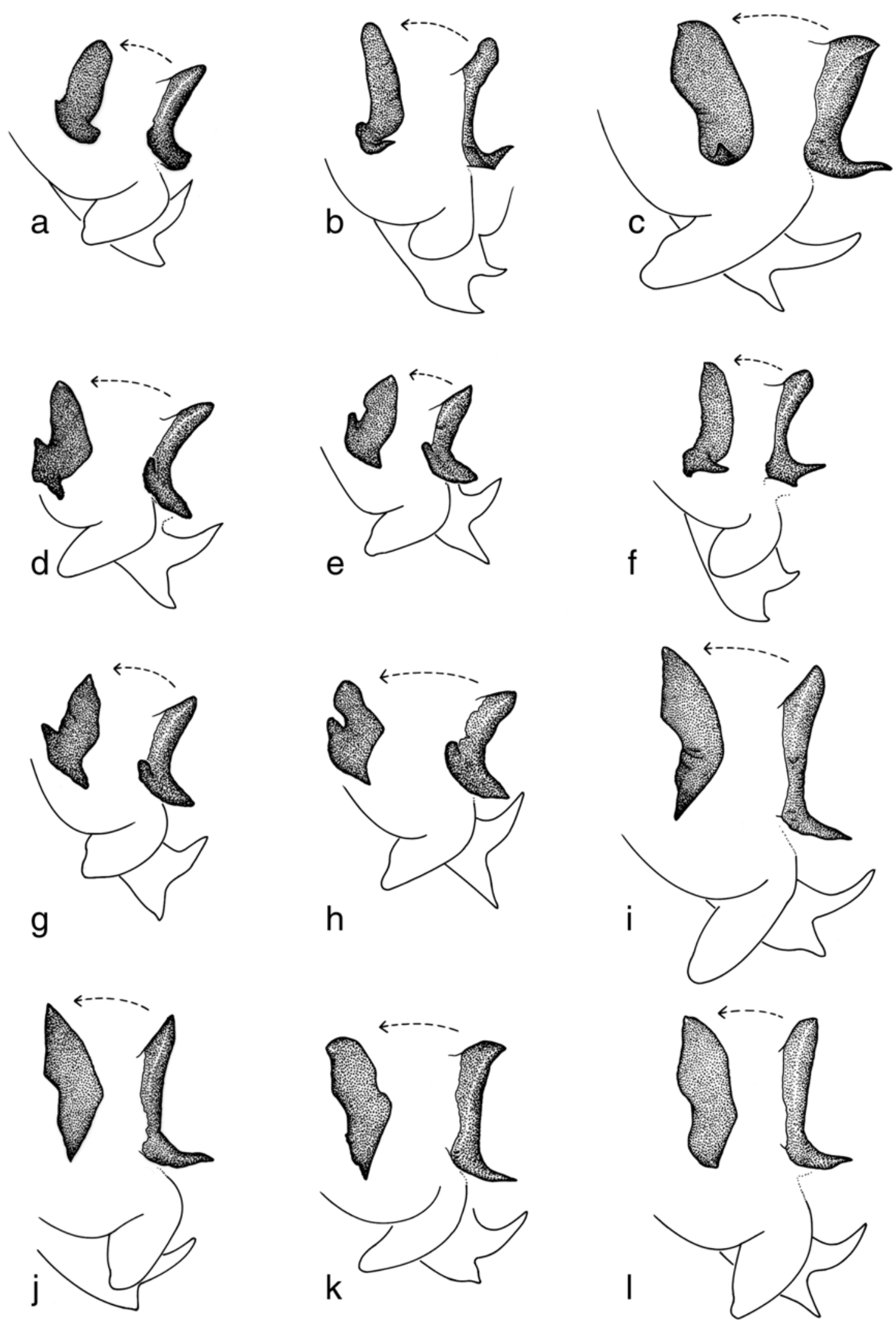

Fig. 17. Sphodropoda tristis, variation in male genitalia, cf figure 13, arrows indicate pa rotated to lateral view. (a) WA—near Wyndham; $(b)$ Qld—near Cooktown; $(c)$ Qld—near Greenvale HS; $(d)$ WA—near Broome; $(e)$ NTOctober Ck; $(f)$ Qld—Townsville; $(g)$ WA—near Millstream HS; $(h)$ NT—near Alice Springs; $(i)$ Qld—Byfield; $(j)$ WA—near Balladonia; $(k)$ Vic-Mallee district; $(l)$ Qld—near Taroom. 
M.F. Chinnick \& J. Walker. $10^{\star}, 1 \mathrm{~km}$ NNE of Millstream HS, $21^{\circ} 35^{\prime} \mathrm{S}$ $117^{\circ} 04^{\prime} \mathrm{E}, 3 \mathrm{Apr} 1971$, Upton \& Mitchell. $30^{\dagger}, 2 \mathrm{~km}$ ENE of Millstream HS, $21^{\circ} 35^{\prime}$ S $117^{\circ} 04^{\prime} \mathrm{E}, 22 \& 30$ Oct \& 4 Nov 1970, M.S. Upton \& J.E. Feehan. 1 ㅇ, Mining Camp, Mitchell Plateau, Kimberley district, $14^{\circ} 49^{\prime} \mathrm{S}$ $125^{\circ} 50^{\prime}$ E, 9-19 May 1983, D.C.F. Rentz \& J. Balderson. 19, $50 \mathrm{~km}$ SW of Sandfire Flat, Broome-Port Hedland Rd, 29 Oct 1978, M.S. \& B.J. Moulds. 1 juv, $8 \mathrm{~km} \mathrm{SW}$ of Walsh Point, Admiralty Gulf, $14^{\circ} 37^{\prime} \mathrm{S}$ $125^{\circ} 48^{\prime}$ E, 17 May 1983, D.C.F. Rentz \& J. Balderson. 1 ㅇ, 2 km NNE of Wyndham Port P.O., $15^{\circ} 27^{\prime}$ S $128^{\circ} 06^{\prime}$ E, 16 Apr 1985, K.H.L. Key. 1 o. Wyndham, 25 Apr 1930, T.G. Campbell (all ANIC). 1 juv, 217 km SE of Broome, 15 Sep 1924, A.S. Cudmore. 1 juv, Forrest River Mission, 8-12 Sep 1953 (both NMV). 10', Bamboo Creek, 20 $56^{\prime}$ S 120 $10^{\circ}$ 'E, 22 Jan 1974, A.M. \& M.J. Douglas. 1 ㅇ, Beverley Springs HS, $16^{\circ} 43^{\prime}$ S $125^{\circ} 27^{\prime} E, 19$ May 1979, B.G. Muir. 10, Cape Range, May 1965, G.W. Kendrick. $1 \delta^{\star}$, Derby, 1962, G. Beamish. 1 đै, Greys Camp, Rudall River, near Larrys Creek, May 1971, K. Clarke \& P. Moore. $10^{\star}, 13 \mathrm{~km}$ ESE of Mooka HS, 24 ${ }^{\circ} 58^{\prime} \mathrm{S}$ $114^{\circ} 49^{\prime}$ E, 9-11 May 1981, B. Hanich \& T.F. Houston. 10, $51 \mathrm{~km}$ SSW of Norseman, 8 Mar 1984, T.F. Houston. 1 , Salmon Gums. 1 tै, Walganna Rock, Austin Downs, $27^{\circ} 43^{\prime}$ S $117^{\circ} 28^{\prime}$ E, 27 Aug 1987, R.P. McMillan. 1 ㅇ․ Winjana Gorge, campsite 13, 12 Apr 1970, Lemley Expedition (all WAM).

Diagnosis. This species can be distinguished from others in the genus by the pattern of tubercles and colouration on the inner face of the foreleg (Fig. 12).

Description. Body (Figs. 7-8) smallish to moderately large. Colour brown with mottled tegmina, green with mottled tegmina or uniform green. Ridge on frontal shield with blunt point at apex. Prothorax with numerous scattered tubercles on dorsal surface, particularly in female; lateral margin finely denticulate; metazone dark grey ventrally, sometimes with orange patch between coxal insertions. Fore leg (Fig. 12) with inner face of coxa dark grey with 6-7 contrasting cream tubercles on anterior margin; inner face of femur orange, with 3-4 small black spots at bases of spines; inner face of first tarsal segment mostly black, of other tarsal segments black apically. Wings of male longer than abdomen, as long as or slightly shorter than abdomen in female; ventral surface of costal area of tegmen rosy red, at least in basal half; discoidal area completely opaque in female, only partly so in male, usually with dark patch on distal margin of stigma (absent in uniformly green specimens and small males of other colour forms); hind wing with costal and discoidal area reddish to yellowish, anal area slightly smoky, particularly toward apex, in female, mostly hyaline in male. Abdomen with median black spot on proximal margin of ventral sclerites $2-5$. Male genitalia (Figs. 13, 17) with relatively short stout $a p r ; p a$ and $d p r$ rather variable, $p a$ compact, shagreened, $\mathrm{L}$ to $\mathrm{C}$ shaped when viewed dorsally, with pointed, laterally directed posterior process and sometimes with blunt pointed, dorsally directed process; $d p r$ terminated with two short, pointed projections of variable form.

Measurements (mm). Body length, of 38-68, of 41-72. Head width, oิ 7-9, o 8-10. Head depth, oิ 4-7, o 6-9. Pronotum length, ô $9-18$, + 11-19. Pronotum width, ơ $3-6$, o 4 4-8. Fore coxa length, ô $6-11$, o 8-13. Fore femur length, 0 7-13, o 10-15. Hind femur length, o $7-13$, 우 $9-14$. Hind tibia length, of 7-13, o 9-14. Tegmen length, oิ 26-46, 우 26-37.

Immature stages. First two instars dark coloured and antlike in appearance and behaviour, the abdomen being curled dorsally when active. Later instars more like adult in behaviour and appearance. Ootheca pale grey or cream, and squat looking. Chapman \& Balderson (1984) recorded a female of this species from Brisbane as laying its oothecae in the ground. This behaviour may not be obligatory however, as I have collected oothecae from the "paper" bark of melaleuca trees in the Cairns region. I have also had females in captivity which laid oothecae on the roof and sides of the container, although oviposition was not observed.

Distribution and habits. Found through most of mainland Australia (Fig. 42), also southeast Papua New Guinea and the Solomon Islands (Beier 1965). The locality of the female type specimen, which cannot be located (Balderson 1984), is recorded as the Fiji Islands (Saussure 1871). This record, however, must remain doubtful until further specimens are obtained. This species is a shrub and tree dweller, usually found on stems or trunks. When disturbed, individuals move to the other side of the stem and flatten themselves against the substrate. Females are capable of at least short flights.

Remarks. This widespread species is quite variable in size and to some extent in the form of the male genitalia (Fig. 17). Specimens from the north west of the continent tend to be smaller (S. mjobergi form) while those from the northeast tend to be larger (typical S. tristis). However, after examining numerous specimens I cannot find any group of characters that would separate one population from the rest. Morphological characters useful in delineating other species within the genera considered here (e.g., pattern on inside of foreleg, head shape) show little or no variation. Thus $S$. mjobergi is considered a synonym of $S$. tristis. I have not been able to locate the holotype of $S$. papua. It is apparently not in the New Guinea Dept. of Agriculture \& Livestock collection, although several paratypes are (F. Dori, pers. comm.), nor is it in the Bishop Museum collection (G. Nishida, pers. comm.). Beier's (1965) description and photograph suggests this species falls well within the range of variation observed for Australian S. tristis and it is therefore considered synonymous. I have examined a syntype of $S$. moesta Giglio-Tos and there is nothing to indicate his species is different from S. tristis. As suggested by Tindale (1923), it is merely the brown colour form of $S$. tristis. The syntype specimen of $S$. moesta examined was listed as the holotype by Balderson (1984). The original description by Giglio-Tos, however, clearly lists two specimens, the second from "the Island of Australia". This second specimen cannot be located in the ZMHU (M. Ohl, pers. comm.). I have also examined two syntypes of $S$. mjobergi and it is obviously the north western form of $S$. tristis. There has been some confusion as to the authorship of the name of this species. Although Saussure described the species he attributed the name tristis to Brunner. Up until recently all subsequent authors except Westwood (1889) attributed the name to Saussure. Balderson et al. (1998), however, attributed the name to Brunner in Saussure, but, as there is no indication that Brunner was responsible for the description, Saussure must be considered the author.

\section{Sphodropoda quinquedens (Macleay)}

$$
\text { Figs. 4-6, 9-10, 14-16, } 43
$$

Mantis quinquedens Macleay, 1826: 454.

Hierodula quinquedens (Macleay).-Saussure, 1871: 78.

Sphodropoda quinquedens (Macleay).-Kirby, 1904: 242. 
Material examined. Lectotype female, Australia (ANIC).

Other specimens examined. Queensland. 19 , Black Mountain

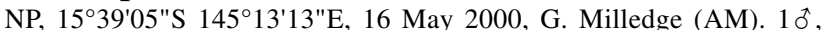
Albatross Hotel, Weipa, $12^{\circ} 38^{\prime} \mathrm{S} 11^{\circ} 52^{\prime} \mathrm{E}, 6$ May 1981, K.H.L. Key. 1 , Annan River, $3 \mathrm{~km} \mathrm{SW}$ of Black Mt., near Cooktown, $15^{\circ} 41^{\prime} \mathrm{S}$ $145^{\circ} 12^{\prime}$ E, 26-27 Apr 1981, D.C.F. Rentz. 10, $44 \mathrm{~km} \mathrm{~N}$ of Cairns, 10 Dec 1982, J.T. Doyen. 1 ㅇ, $8 \mathrm{~km} \mathrm{~W}$ of Dimbulah, $17^{\circ} 09^{\prime} \mathrm{S} 145^{\circ} 02^{\prime} \mathrm{E}, 22$ Mar 1988, D.C.F. Rentz. 1 đ, Emu Creek, $27 \mathrm{~km} \mathrm{SW}$ of Dimbulah, $17^{\circ} 20^{\prime}$ S $144^{\circ} 57^{\prime} \mathrm{E}, 25-26$ Nov 1981, J. Balderson. 1 ㅇ, Iron Range, 12 Jul 1969, J.C. Le Souëf. 10, McKenzie River crossing, $75 \mathrm{~km}$ NNE of Dingo, 17 Jan 1987, M.S. \& B.J. Moulds. 1 juv, Shiptons Flat, near Cooktown, $15^{\circ} 47^{\prime}$ S $145^{\circ} 14^{\prime}$ E, 16-18 May 1981, D.C.F. Rentz. 10, Silver Plains HS, Cape York Pen., 25 Apr 1968, J.L. Wassell (all ANIC). 1 ô, Annan River crossing, $2 \mathrm{~km} \mathrm{~S}$ of Cooktown, 4 Apr 1991, G. Milledge. 1 ㅇ, Brisbane, 12 Oct 1914, J. Frost. $1 \delta^{\star}, 1 \mathrm{~km}$ NNE of Collins Weir, W of Atherton, $17^{\circ} 15^{\prime} \mathrm{S} 145^{\circ} 17^{\prime} \mathrm{E}, 10 \mathrm{Feb} 1989$, G. Milledge. $10^{\top}, 8 \mathrm{~km} \mathrm{E}$ of Emuford, 30 Dec 1989, M.S. \& B.J. Moulds. $10^{\star}$, Jardine River ferry crossing, $50 \mathrm{~km} \mathrm{~S}$ of Bamaga, $11^{\circ} 05^{\prime} \mathrm{S} 142^{\circ} 18^{\prime} \mathrm{E}$, K. Walker. 1 , Poison Creek Rd, 10 km W of Cooktown, 4 Apr 1991, G. Milledge (all NMV).

Western Australia. 1 juv, $8 \mathrm{~km}$ SW of Walsh Point, Admiralty Gulf, $14^{\circ} 37^{\prime}$ S $125^{\circ} 48^{\prime}$ E, 17 May 1983, D.C.F. Rentz \& J. Balderson (ANIC).

Diagnosis. Sphodropoda quinquedens can be separated from the other species of this genus by the distinctive pattern on the inside face of the fore leg (Fig. 15), the colour markings on the ventral surface of the costal area of the tegmen and the form of the male genitalia (Fig. 16).

Description. Body (Figs. 9-10) moderately large. Colour brown with mottled tegmina, green with mottled tegmina or uniform green. Ridge on frontal shield with blunt point at apex. Prothorax with numerous scattered tubercles on dorsal surface, particularly in female; lateral margin finely denticulate, slightly lamellate in prozone. Fore leg (Fig. 15) with inner face of coxa purplish in posterior half, anterior half orange brown with 6 contrasting pointed cream tubercles on anterior margin which extend basally as ridges across surface; inner face of femur without markings; inner face of first tarsal segment mostly black, of other tarsal segments black apically. Wings of both sexes longer than abdomen; ventral surface of costal area of tegmen rosy red on inner half, outer half black, whole area crossed with slender white bands and spots; discoidal area completely opaque in female, only partly so in male; hind wing with costal and discoidal area yellowish, anal area slightly smoky, particularly toward apex, in female, mostly hyaline in male. Male genitalia (Fig. 16) with apr relatively elongate and narrow distally; $p a$ compact, shagreened, with anterior pointed lateral projection and broad blunt posterior projection; $d p r$ with anterior projection much longer than posterior one.

Measurements (mm). Body length, ô 64, $q 70$. Pronotum length, ot 16, o 21. Pronotum width, ot 6 , $q 9$. Fore coxa length, $\delta, 11$, +15 . Fore femur length, $\delta 13$, ㅇ 18. Hind femur length, $\delta 10$, ㅇ 14 . Hind tibia length, $\tau 10$, o 16 . Tegmen length, ô 46, of 46 .

Immature stages. Early stages and ootheca unknown.

Distribution and habits. Found in north eastern Queensland and one record from north Western Australia (Fig. 43). This species displays cryptic behaviour similar to that described above for $S$. tristis. This behaviour has been noted previously in S. quinquedens (Heath \& Cowgill, 1989).

\section{Sphodropoda viridis Tindale}

Figs. 18-19, 36-38, 44

Sphodropoda viridis Tindale, 1923: 446.

Material examined. Holotype male, Mount Painter, Flinders Range, South Australia, H.G. Stokes, I 14061 (SAM).-QUEENSLAND. 2 \$, 27 km SE of Cunnamulla, 27 Mar 1972, R.C. Lewis (ANIC). $10^{\text {o, Gilbert }}$ River, 27 Mar 1990, J. Hasenpusch. 2 ơ, Georgetown, 13 \& 14 Apr 1991, G. Milledge (all NMV). 1 \&, Cunnamulla, H. Hardcastle (SAM).-NEW South WALES. 1 đै, 1 \% , Trangie, 21 Apr 1956, L.J. Chinnick (ANIC).NORTHERN TERRITORY. 19 , Barrow Creek Tel.Sta., 20 Mar 1955, K.H.L. Key. 5 ô, Clay Pan Well, 38 km NW of Tanami, 12 Apr 1963, L.J.

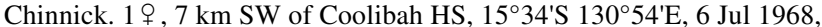
M. Mendum (all ANIC). $1 \delta^{\widehat{t}}$, Tourist Camp site, Ormiston Gorge National Park, Horn Centenary Expedition, $23^{\circ} 38^{\prime} 03^{\prime \prime S} 132^{\circ} 43^{\prime} 23^{\prime \prime E}, 10$ Mar 1995, P. Swinkels (NMV).-South Australia. 1 đo , Mt. Painter, Flinders Range, H.G. Stokes (SAM).-VICTORIA. 19 , Mildura Gun Club, 27 Mar 1990, P. Robertson (NMV).-WESTERN AUSTRALIA. 10 , $17 \mathrm{~km}$ NE of Cane River HS, $21^{\circ} 56^{\prime} \mathrm{S} 115^{\circ} 39^{\prime} \mathrm{E}, 27$ Apr 1971, Key, Upton \& Mitchell. 10 , $3 \mathrm{~km}$ NNW of Mandora HS, SSW of Broome, 17 Apr 1963, L.J. Chinnick. $10^{\circ}, 1 \mathrm{~km} \mathrm{~N}$ of Millstream HS, $21^{\circ} 35^{\prime} \mathrm{S} 117^{\circ} 04^{\prime} \mathrm{E}, 15 \mathrm{Apr}$ 1971, Upton \& Mitchell. 10, 1 $9,43 \mathrm{~km} \mathrm{NW}$ of Wittenoom, $22 \mathrm{Apr}$ 1963, L.J. Chinnick. 1 1 , 5 km N of Wittenoom, 21 Apr 1963, L.J. Chinnick. 1 \%, 48 km ESE of Wittenoom, 25 Apr 1963, L.J. Chinnick (all ANIC). 10 , Hancock Gorge, $15 \mathrm{~km} \mathrm{~S}$ of Wittenoom, 15 May 1980, G. Marney \& P. Duncan. 1 \%, Minilya. 1 \% , $2.5 \mathrm{~km}$ E of Marandoo Camp, $22^{\circ} 38^{\prime} \mathrm{S} 118^{\circ} 06^{\prime} \mathrm{E}, 5-19$ May 1980 , T.F. Houston (all WAM).

Diagnosis. This species can be distinguished by the uniform green colouration, lack of markings on the inner face of the fore coxa (Fig. 37) and the form of the male genitalia (Fig. 38).

Description. Body (Figs. 18-19) medium to rather large. Colour uniform green. Ridge on frontal shield with blunt point at apex. Prothorax with a few scattered tubercles on dorsal surface, more so in female; lateral margin finely denticulate. Fore leg (Fig. 37) with inner face of coxa without markings, anterior margin with 7-10 denticles; inner face of femur with two small dark spots at base of spines; inner face of all tarsal segments black. Wings of male longer than abdomen, those of female as long as or longer than abdomen; ventral surface of costal area of tegmen reddish; discoidal area completely opaque in female, only partly so in male; hind wing with costal and discoidal area yellowish, anal area mostly hyaline. Abdomen with median black spot on proximal margin of ventral sclerites 2-5. Male genitalia (Fig. 38) apr of moderate length; $p a$ with smooth, pointed elongate anterior projection, shagreened and blunt posteriorly; distal projections of $d p r$ short and broad, one directed anterolaterally, the other posterodorsally.

Measurements (mm). Body length, ô 48-64, ㅇ 44-60. Pronotum length, ô 12-18, ㅇ 14-19. Pronotum width, $\hat{\sigma}$ 3.5-6, ㅇ 5-6.5. Fore coxa length, ô 9-11, ㅇ 9-12.5. Fore femur length, ơ 9-12, ㅇ 10-14. Hind femur length, ô 812, ㅇ 9-12. Hind tibia length, ơ 8.5-14, 우 11-14. Tegmen length, ơ 36-47, 우 30-40.

Immature stages. Immature stages and ootheca unknown.

Distribution and habits. Found across the drier parts of the continent (Fig. 44). This species displays cryptic behaviour similar to that described for $S$. tristis and $S$. quinquedens. 


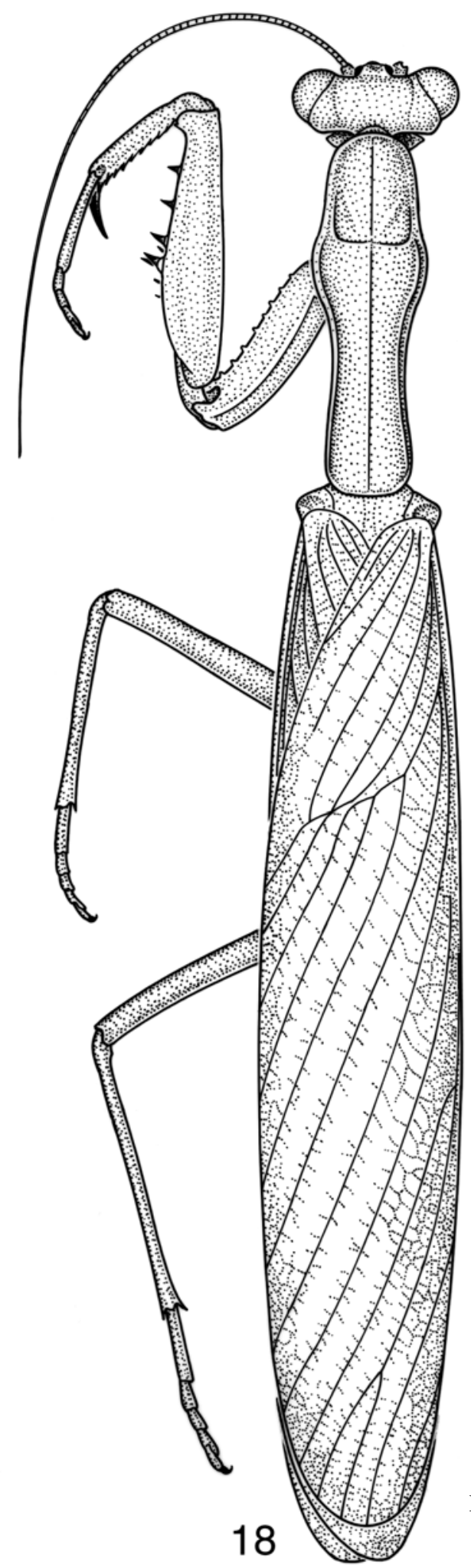

Sphodropoda lepida n.sp.

Figs. 20-23, 43

Material examined. HOLOTYPE $\widehat{\delta}$, Uluru campsite, Horn Centenary Expedition, $25^{\circ} 23^{\prime} 10^{\prime \prime} \mathrm{S} 131^{\circ} 00^{\prime} 46^{\prime \prime E}$, Northern Territory, 25 Mar 1995, G. Milledge (NMV). PARATYPES $(7 \hat{0} \hat{0}): 1 \hat{0}$, Ayers Rock, Northern Territory, 16 Feb 1967, M.S. Upton; $6 \hat{o}^{\hat{\sigma}}, 56 \mathrm{~km} \mathrm{~W}$ of Amata, Musgrave Ranges, $26^{\circ} 09^{\prime} \mathrm{S} 130^{\circ} 35^{\prime} \mathrm{E}$, South Australia, 20-21 Jan 1982, D.C.F. \& B.G.F. Rentz \& R. Honeycutt (all ANIC).

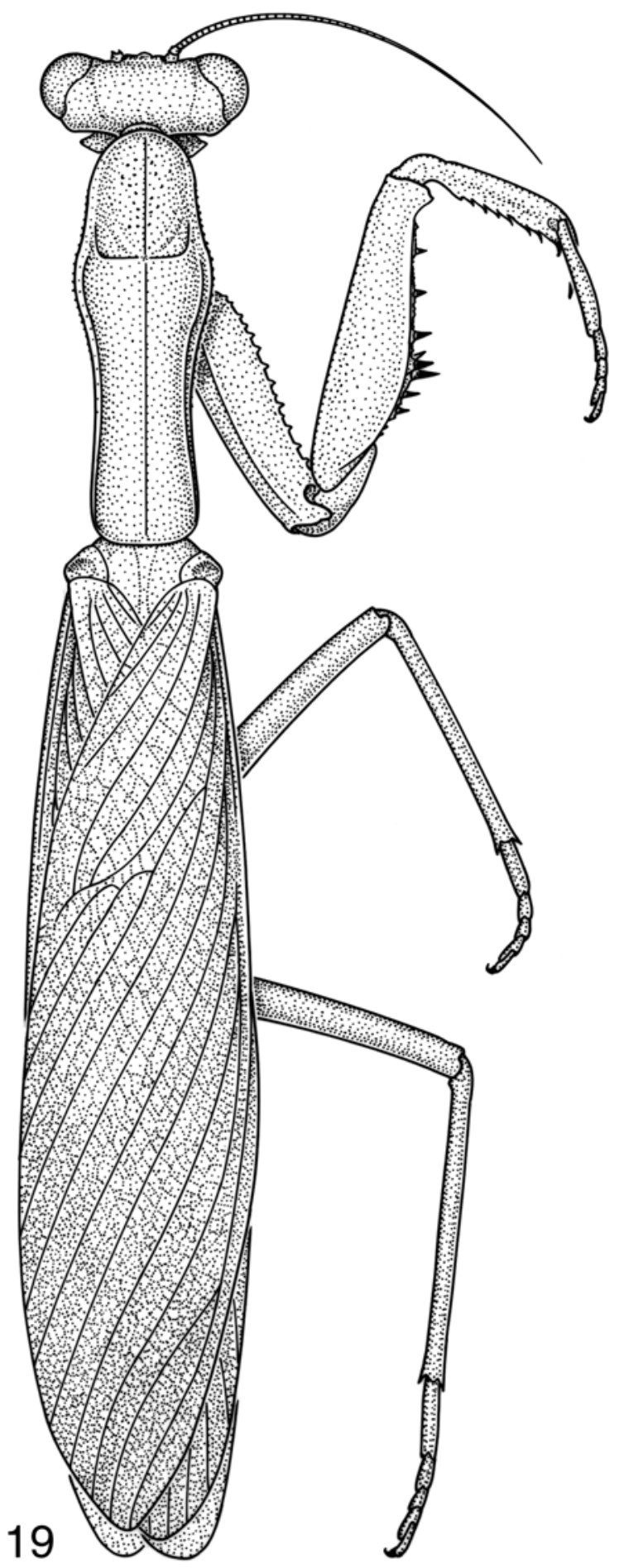

Figs. 18-19. Sphodropoda viridis. (18) Male, dorsal; (19) female, dorsal. Scale $=10 \mathrm{~mm}$.
Diagnosis. This species can be distinguished by the lack of markings on the inner face of the fore coxa (Fig. 22), the banded tegmina (Fig. 20) and the form of the male genitalia (Fig. 23).

Description. Male only, female unknown. Medium sized species. Body colour partly green and partly purplish brown. Head (Fig. 21) purplish brown; narrower than other species in the genus, ridge on frontal shield without blunt point at apex. Prothorax purplish brown, paler at margins; with a few scattered tubercles on dorsal surface; lateral margin 


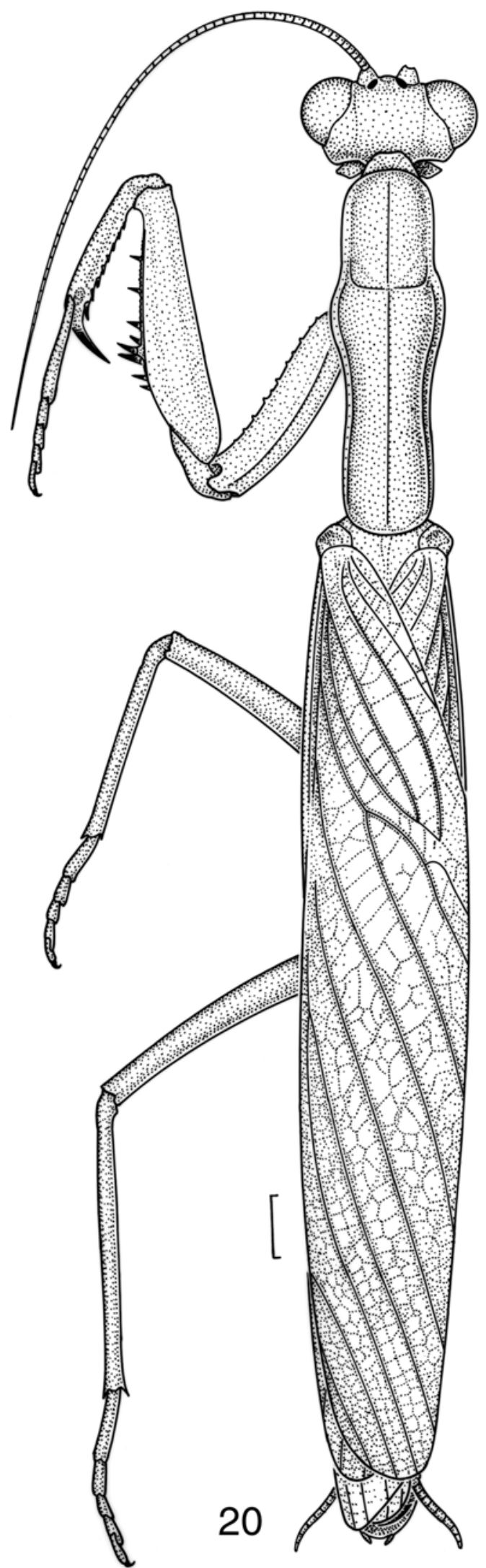

finely denticulate. Fore legs green; inner face of coxa without markings (Fig. 22), anterior margin with 7 denticles; inner face of fore femur with three small dark spots at base of spines; inner face of all tarsal segments black. Mid and hind legs green. Wings about as long as abdomen; dorsal and ventral surface of costal area of tegmen purplish,

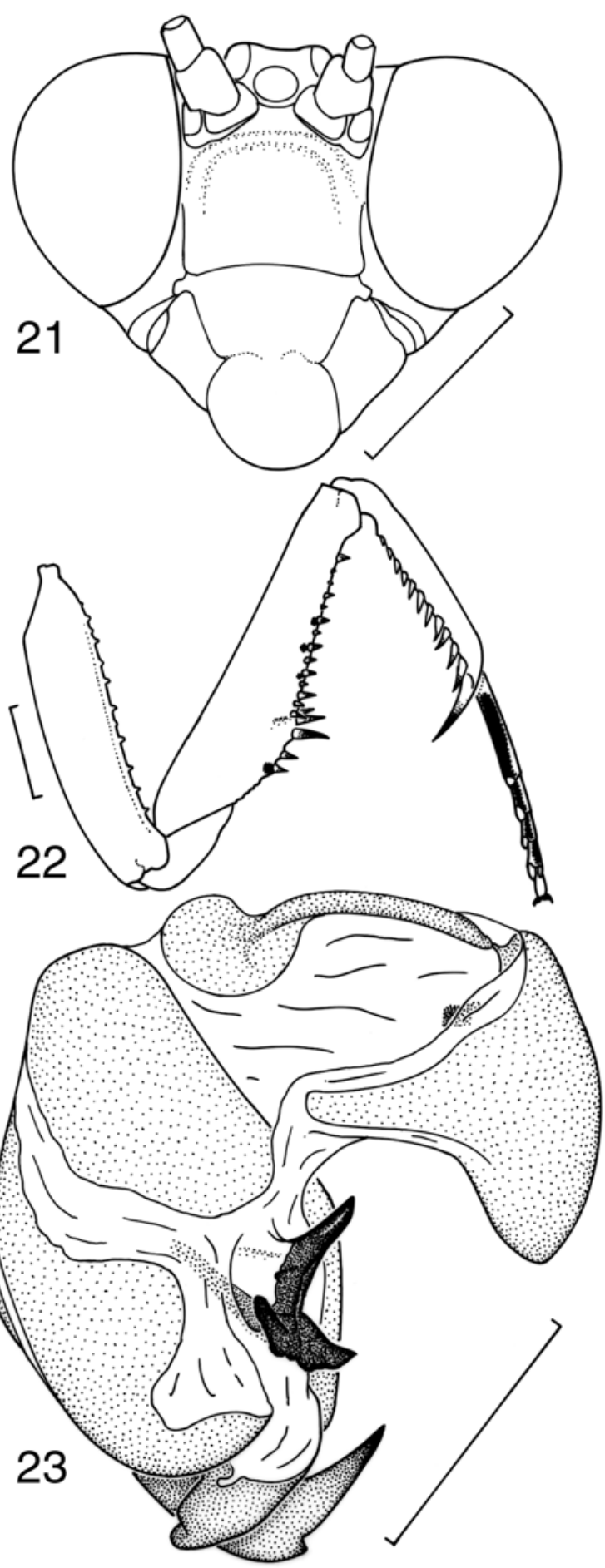

Figs. 20-23. Sphodropoda lepida, male. (20) Dorsal view; (21) head, anterior view; (22) fore leg, internal view; (23) genitalia, dorsal view. Scales $=2 \mathrm{~mm}$.

stronger beneath, with narrow whitish marginal band; discoidal green along anterior margin, major veins flushed with purplish brown giving banded appearance, remainder hyaline; hind wing with costal and discoidal area greenish, anal hyaline. Abdomen with median black spot on proximal margin of ventral sclerites 2-5. Male genitalia (Fig. 23) with short, broad apr; pa with smooth, pointed anterior projection, shagreened posteriorly with pointed lateral and blunt dorsal projections; apr with anterior projection moderately elongate, posterior one extremely short. 


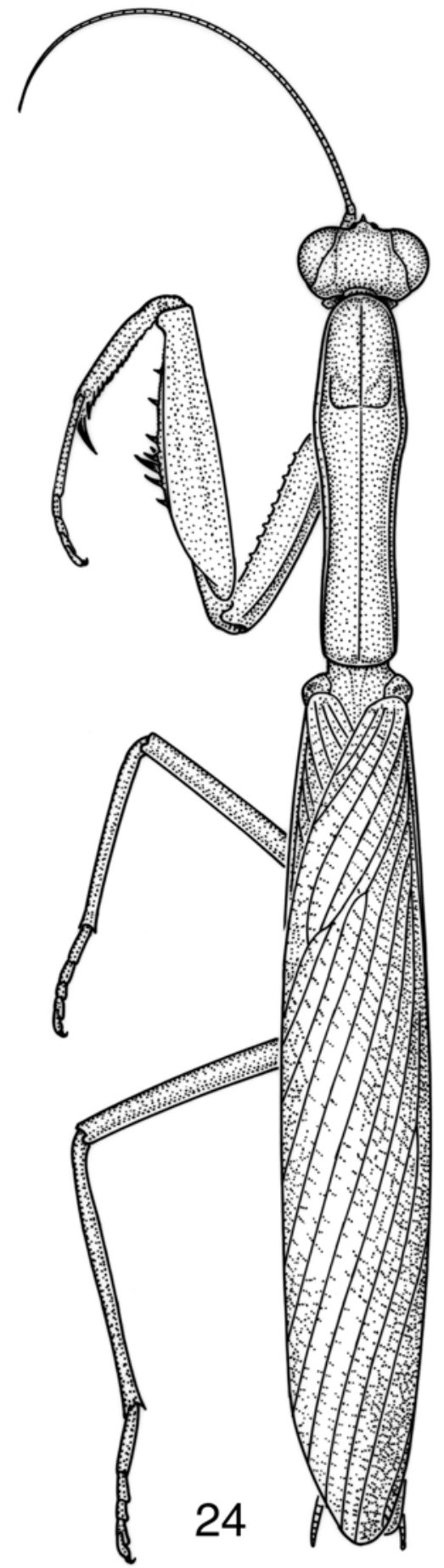

Figs. 24-25. Trachymantis obesa. (24) Male, dorsal; (25) female, dorsal. Scale $=10 \mathrm{~mm}$.

Measurements (mm, paratype male). Body length, ô 46. Pronotum length, ô 12. Pronotum width, ô 4 . Fore coxa length, $\delta 9$. Fore femur length, $\delta 11$. Hind femur length, o 8.5. Hind tibia length, ô 10 . Tegmen length, ô 32.

Immature stages. Immature stages and ootheca unknown.

Distribution and habits. At present, only known from central Australia (Fig. 43). Habits unknown but likely to be similar to other members of the genus.

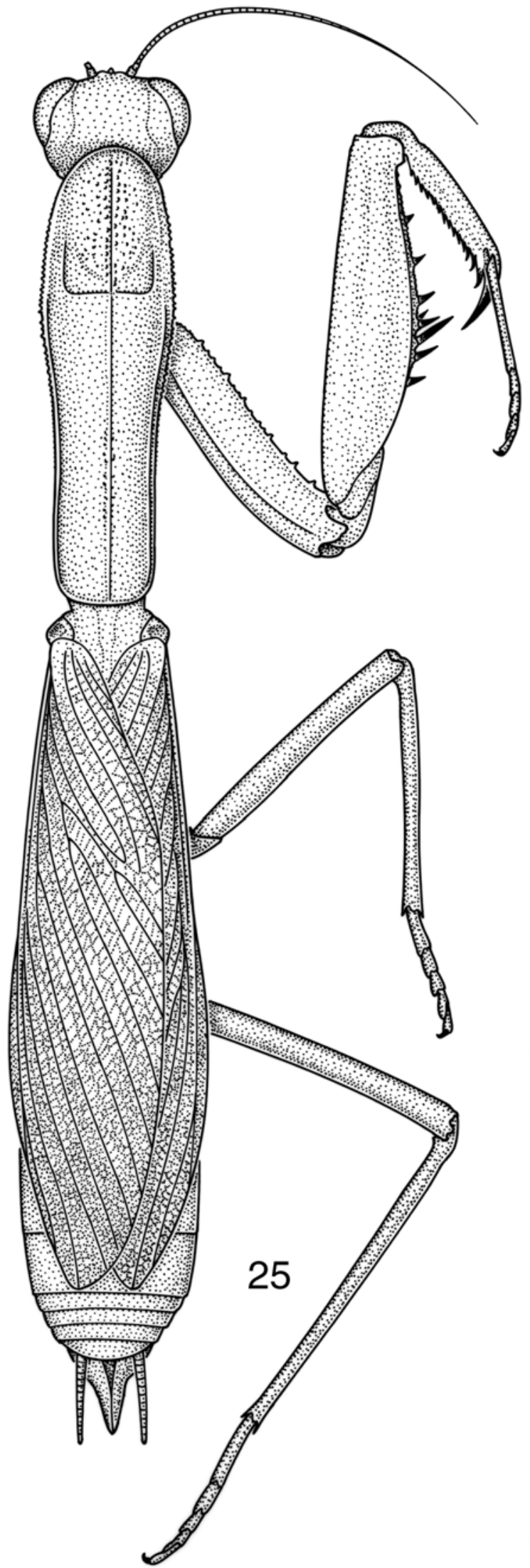

Trachymantis Giglio-Tos

Trachymantis Giglio-Tos, 1917: 47. Type species Trachymantis obesa Giglio-Tos, by monotypy.

Ngawala Tindale, 1923: 447. Type species Ngawala dentifrons (Stål), by original designation. 


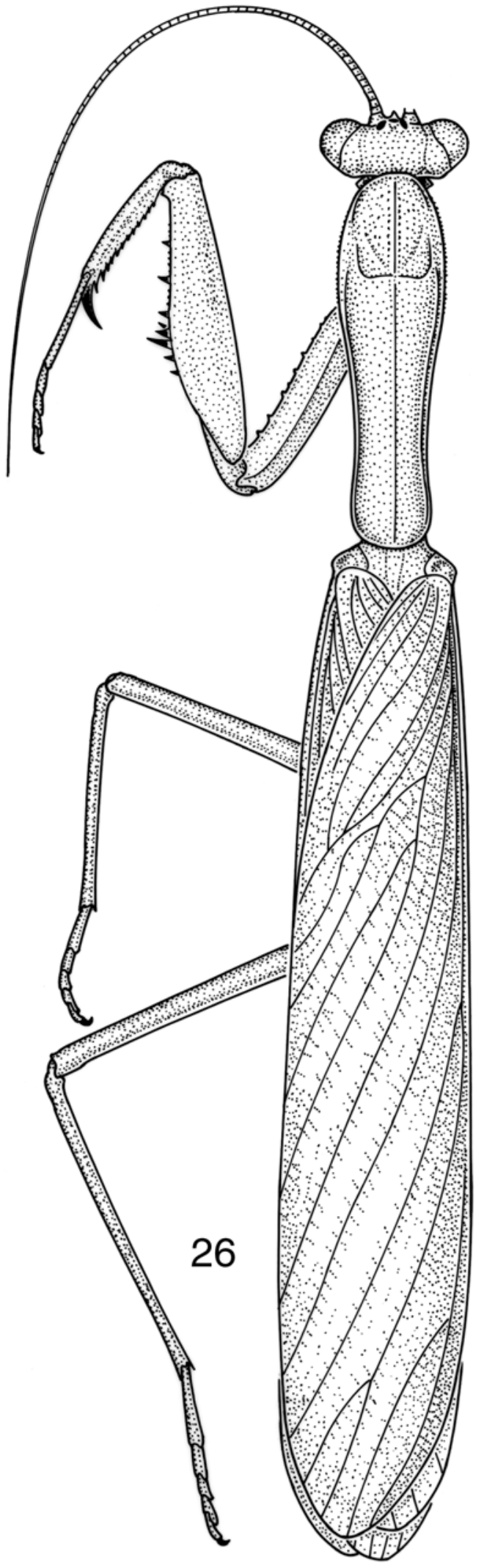

Diagnosis. Head about as high as wide or higher than wide, frontal shield with pronounced tooth at apex; preacetabular spine strong; ventral face of fore femur tuberculate, especially toward outer margin; male macropterous, female brachypterous, ventral face of costal area of tegmen partially dark grey, mid and hind legs normal. Can be distinguished

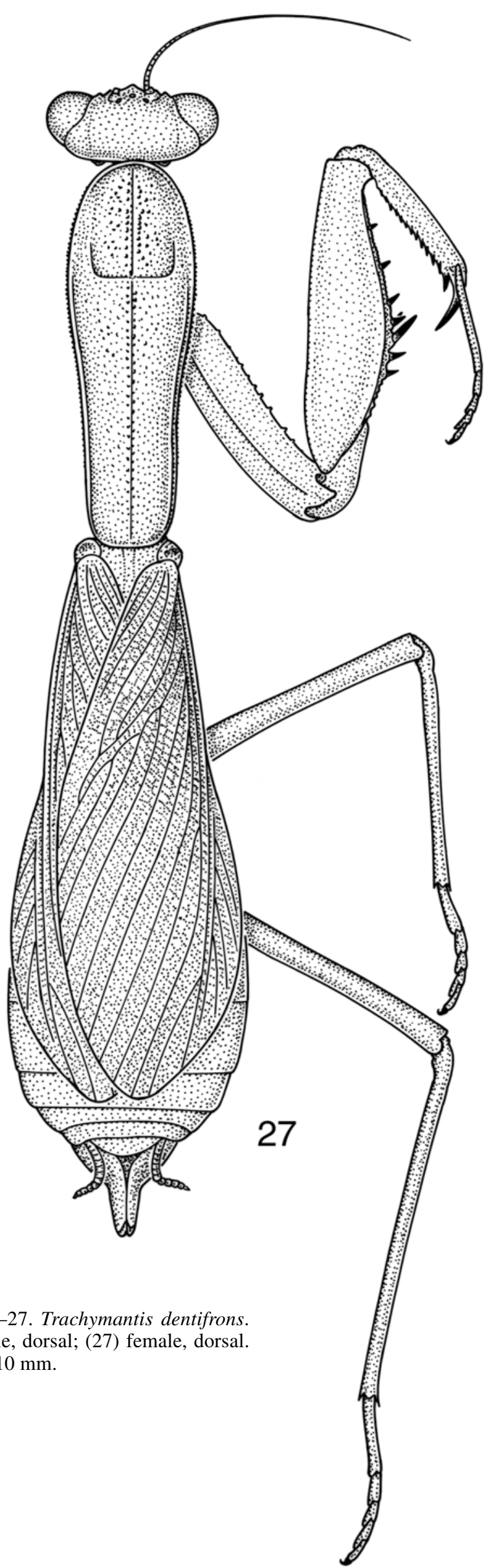




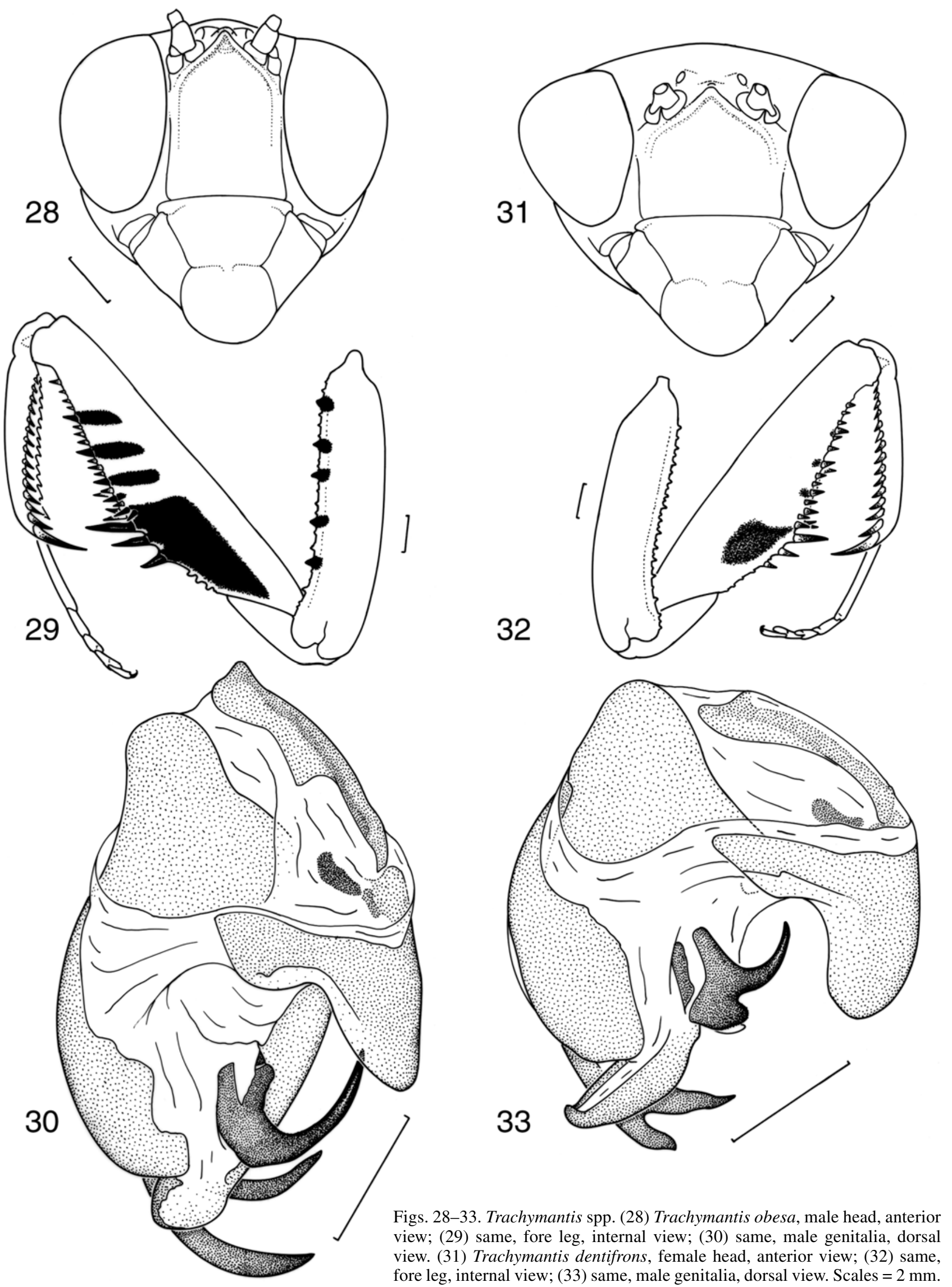



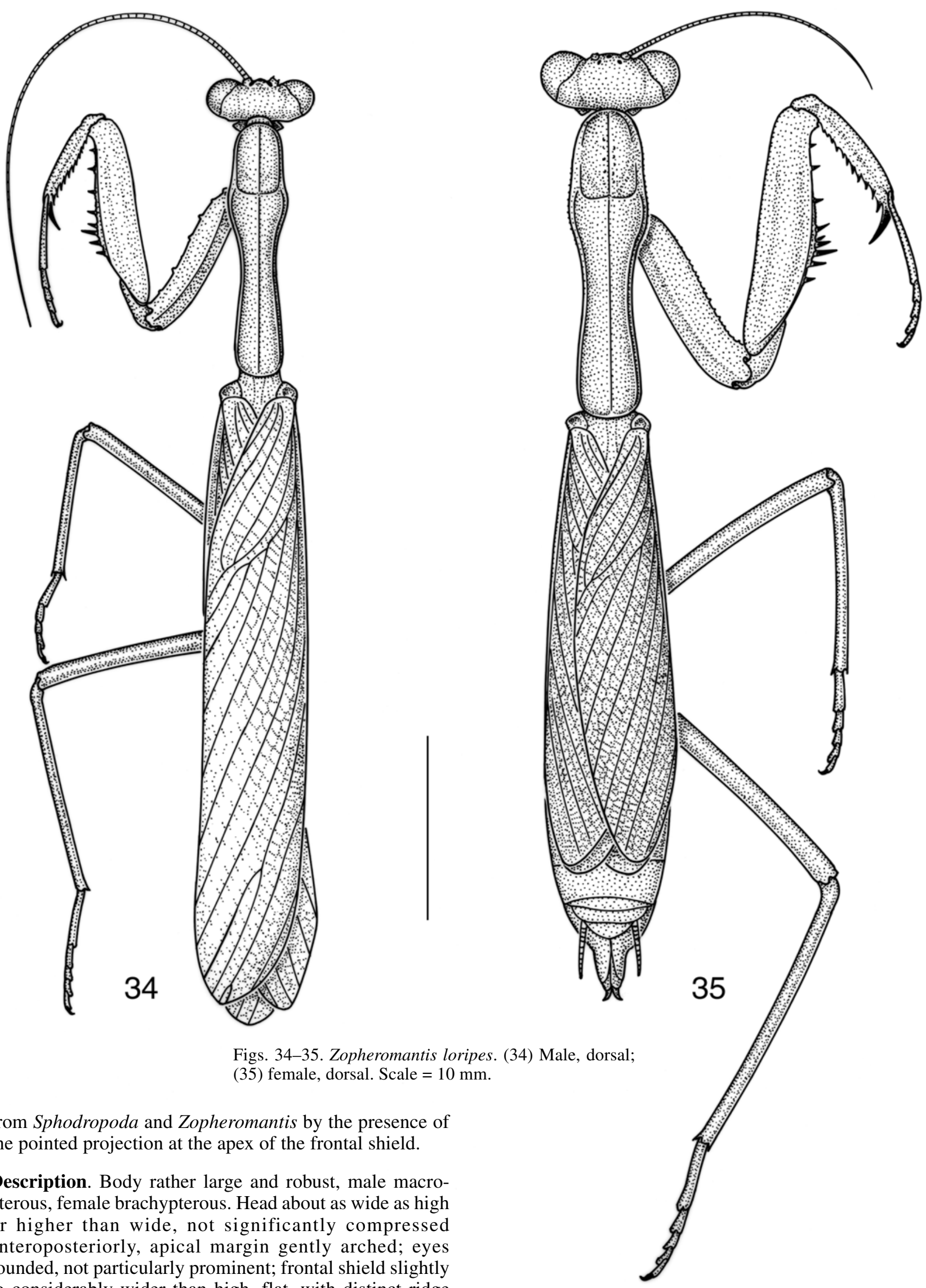

from Sphodropoda and Zopheromantis by the presence of the pointed projection at the apex of the frontal shield.

Description. Body rather large and robust, male macropterous, female brachypterous. Head about as wide as high or higher than wide, not significantly compressed anteroposteriorly, apical margin gently arched; eyes rounded, not particularly prominent; frontal shield slightly to considerably wider than high, flat, with distinct ridge laterally and apically produced into a tooth at apex. Pronotum moderately elongate, supracoxal expansion distinct, dorsal surface finely granulate, mostly in prozone, 

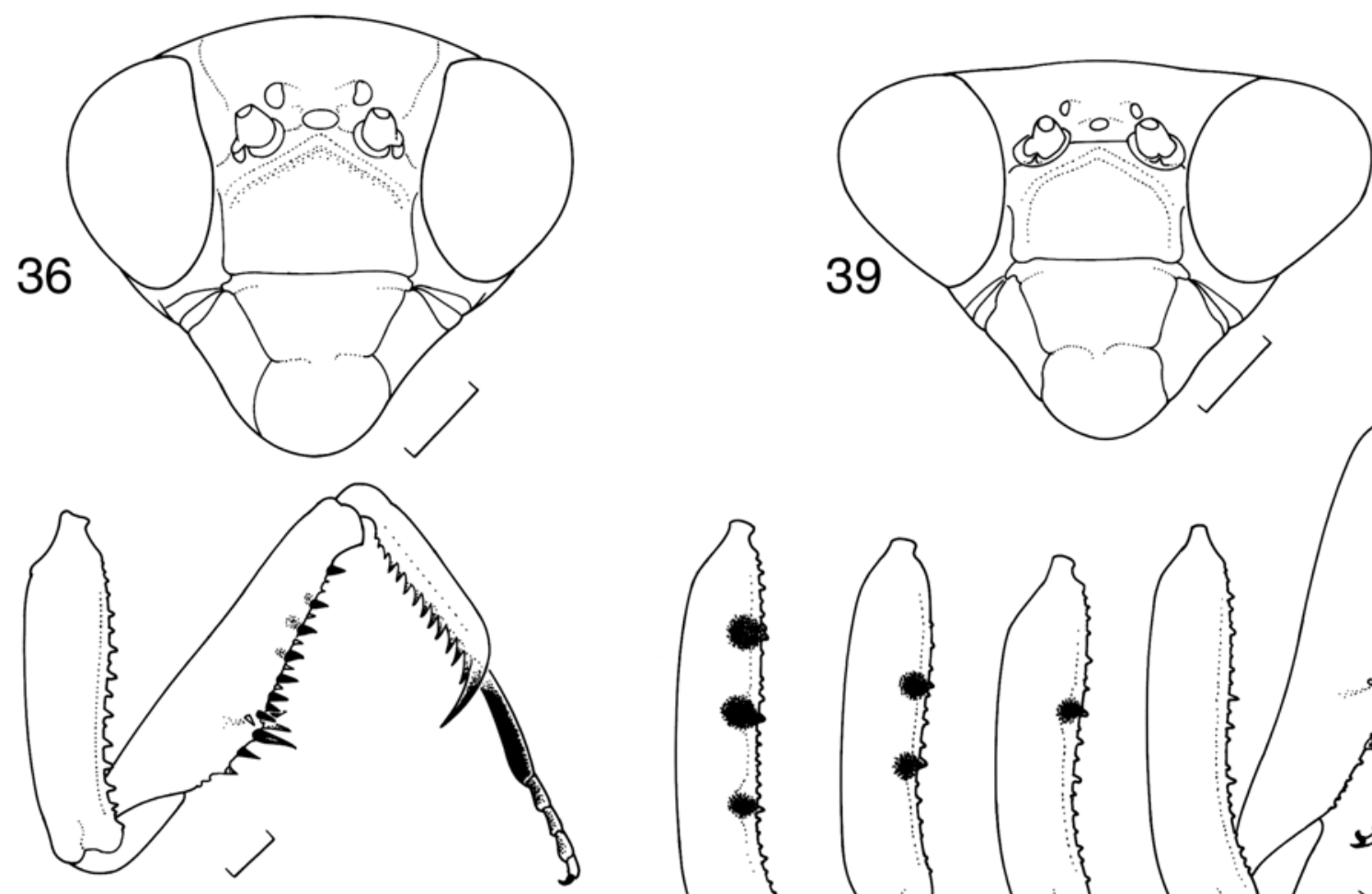

37
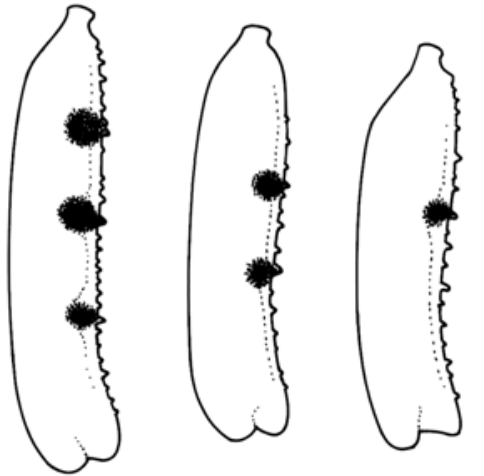

40
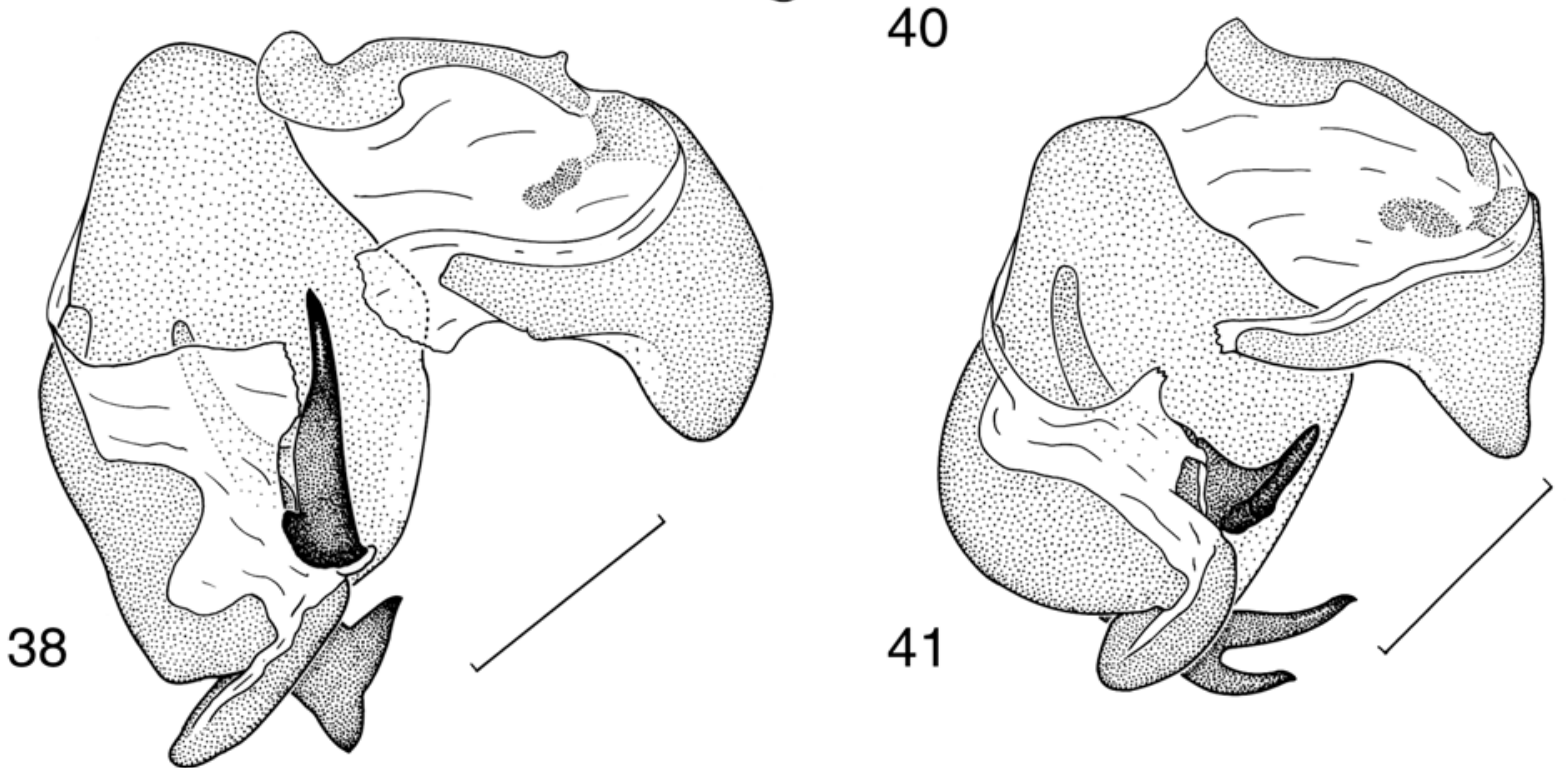

Figs. 36-41. Sphodropoda viridis and Zopheromantis loripes. (36) Sphodropoda viridis, female head, anterior view; (37) same, fore leg, internal view; (38) same, male genitalia, dorsal view; (39) Zopheromantis loripes female head, anterior view; (40) same, fore leg, internal view showing variation in coxal pattern; (41) same, male genitalia, dorsal view. Scales $=2 \mathrm{~mm}$.

margins finely denticulate, ventral surface with preacetabular spine prominent. Fore coxa as long as metazone of pronotum, with or without markings, a number of denticles on anterior margin. Fore femur finely tuberculate on ventral surface, particularly toward outer margin; with four discoidal spines, relative length longest to shortest 3-2-1-4; with four outer and 15-18 inner spines, claw groove situated at about a third the total distance from base. Tegmen with costal area opaque, partially grey beneath; discoidal area entirely opaque to mostly hyaline. Hind wing with costal and discoidal area pigmented, anal area largely hyaline. Mid and hind legs normal, hind femur more than half the length of abdomen. Abdomen moderately elongate, cerci short, slender and cylindrical. Male genitalia with $d p r$ bifurcate.

\section{Key to species of Trachymantis}

1 Facial shield much higher than wide T. obesa

Facial shield about as high as wide T. dentifrons 


\section{Trachymantis obesa Giglio-Tos}

Figs. 24-25, 28-30, 45

Trachymantis obesa Giglio-Tos, 1917: 47.

Material examined. Holotype female, Hermannsburg, Central Australia, H.J.Hillier, 1911-311 (BMNH).-QuEENSLAND: $20,3 \mathrm{~km}$ W of Bundeena HS, SW of Quilpie, 12 Feb 1972, R.C. Lewis. 1 \% 14 $\mathrm{km} \mathrm{S}$ of Quilpie, 14 Nov 1971, R.C. Lewis. 10 , $5 \mathrm{~km} \mathrm{~N}$ of Eromanga, 3 Nov 1967, R.C. Lewis (all ANIC).-New South WaLES: $2 \hat{0}, 18 \mathrm{~km}$ WNW of Bourke, 9 Feb 1972, R.C. Lewis (ANIC).-NORTHERN TERRITORY: $10^{\hat{n}}$, Wigley Waterhole, $8 \mathrm{~km} \mathrm{~N}$ of Alice Springs, $16 \mathrm{Feb}$ 1966, Britton, Upton \& McInnes. $19,22 \mathrm{~km}$ NNW of Kulgera HS, 8 Oct 1955, L.J. Chinnick. 1 juv, 37 km N of Alice Springs, 17 Nov 1966, White, Blackith \& Blackith (all ANIC). 1 \% , Kathleen Creek, Watarrka National Park, 2420'38"S 13140'54"E, 21 Oct 1994, G. Milledge (NMV).-WESTERN Australia: $20,10 \mathrm{~km}$ NE of Menzies, 14 Jan 1989 , M.S. \& B.J. Moulds. 1 đิ, 55 km ESE of Mount Magnet, 18 Jan 1989 , M.S. \& B.J. Moulds. 10, $110 \mathrm{~km} \mathrm{~S}$ of Mount Magnet, 19 Jan 1989, M.S. \& B.J. Moulds. $2{ }^{\widehat{\alpha}}, 25 \mathrm{~km}$ E of Sandstone, 17 Jan 1989, M.S. \& B.J. Moulds.

Diagnosis. Can be distinguished from T. dentifrons by the facial shield being higher than wide.

Description. Body (Figs. 24-25) rather large. Colour uniform green or bluish green. Head (Fig. 28) higher than wide; frontal shield distinctly higher than wide with ridge produced into prominent point at apex. Prothorax with fine scattered tubercles on dorsal surface, mostly in prozone, more so in female; lateral margin finely denticulate. Fore leg (Fig. 29) with inner face of coxa bluish, apricot on distal quarter, anterior margin with five black spots and 11-12 small denticles; inner face of fore femur apricot in lower half with large black patch proximally and three narrow black bands distally; inner face of fore tibia orange. Wings of male longer than abdomen, those of female slightly shorter than abdomen; ventral surface of costal area of tegmen dark bluish grey with narrow apricot marginal band; discoidal area completely opaque in female, only partly so in male; hind wing with costal and discoidal area yellowish green, anal area mostly hyaline. Male genitalia (Fig. 30) with very short blunt $a p r ; p a$ with single, elongate hooklike projection; distal projections of $d p r$ elongate, narrow and of similar length.

Measurements (mm). Body length, ô 54-70, ㅇ 72-75. Pronotum length, $\delta$ 17-20, $q$ 24-26. Pronotum width, $\delta$ 4.5-6, ㅇ 8. Fore coxa length, of 14-17, 우 16-18. Fore femur length, ô 12-14, of 21-22. Hind femur length, ô $11-15$, o 18. Hind tibia length, o $12-16$, ㅇ 20. Tegmen length, ô 34-46, o 34-37.

Immature stages. Later instar nymphs similar in appearance to adults, early instars and ootheca unknown.

Distribution and habits. Recorded (Fig. 45) from the drier parts of Queensland, New South Wales, Northern Territory and Western Australia. The single specimen I have collected was found in a large Acacia shrub. Whilst in captivity it did not display cryptic behaviour as found in Sphodropoda.

\section{Trachymantis dentifrons (Stål, 1877) n.comb.}

Figs. 26-27, 31-33, 46

Hierodula (Sphodropoda) dentifrons Stål, 1877: 56. Sphodropoda dentifrons (Stål), Kirby, 1904: 242. Ngawala dentifrons (Stål), Tindale, 1923: 447.
Material examined. Two syntype females, Australia, Boucard (NHRM).

Other material. NEW SOUTH WALES: $10,3 \mathrm{~km}$ NW of Bramah HS, NW of Balranald, $34^{\circ} 24^{\prime}$ S $143^{\circ} 14^{\prime}$ E, 24 Oct 1983, D.C.F. Rentz \& M.S. Harvey. 10 , $26 \mathrm{~km} \mathrm{~S}$ of Pooncarie, 21 Jan 1980, M.J.D. White (both ANIC).-NORTHERN TERRITORY: $10,17 \mathrm{~km}$ SSE of Mt. Harris, 25 Aug 1955, L.J. Chinnick (ANIC). $2 \widehat{0}$, Uluru Camp Site, Horn Centenary Expedition, $25^{\circ} 23^{\prime} 10^{\prime \prime S} 131^{\circ} 00^{\prime} 46^{\prime \prime E}, 24$ \& 25 Oct 1994, G. Milledge. $10^{\top}$, Uluru Mallee site, Horn Centenary Expedition, $25^{\circ} 24^{\prime} 07^{\prime \prime S}$

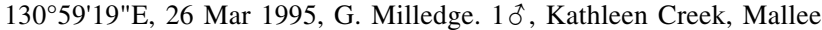
site, Horn Centenary Expedition, Watarrka NP, 2420'54"S 131 40 '36"E, 24 Mar 1995, P. Lilywhite (all NMV).-SOUTH AUSTRALIA: 2 juv, Lowan Stn., 7 km S of Sherlock, 4 Mar 1953 \& 20 Dec 1954, L.J. Chinnick. 2 juv, Lowan Stn., $7 \mathrm{~km} \mathrm{~S}$ of Sherlock, 9 Mar 1953. 1 के, $56 \mathrm{~km} \mathrm{~W}$ of Amata, Musgrave Ranges, $26^{\circ} 09^{\prime} S 130^{\circ} 35^{\prime} \mathrm{E}, 20-21$ Jan 1982, D.C.F.

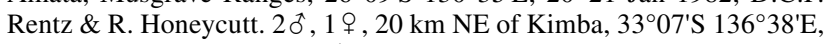
5 Oct 1982, D.C.F. Rentz. $1 \delta^{\dagger}$, Brachina Gorge, Flinders Ranges, 9 Nov 1987, J.C. Cardale. 2 juv, 13 km WNW of Minnipa, 22 Oct 1968, J. Balderson \& M.S. Upton. 1 juv, 5 km SSE of Minnipa, 30 Oct 1969, Key \& Upton. $10^{\star}, 18 \mathrm{~km} \mathrm{SSW}$ of Pinnaroo, $35^{\circ} 24^{\prime} \mathrm{S} 140^{\circ} 48^{\prime} \mathrm{E}, 25$ Oct 1983, D.C.F. Rentz \& M.S. Harvey. $1 \hat{0}, 1.5 \mathrm{~km}$ ESE of Ooldea, 3 Oct 1968, Key, Upton \& Balderson (all ANIC). 1 으, Overland Railway, 40 $\mathrm{km}$ W of Kychering Soak, Dec 1908, Mr Chandler (NMV). 1 ô, Darke's Peak, R.G. Walsh (SAM)._-VICTORIA: 1 , Big Desert, P. Robertson. 1 ㅇ, Big Desert, $35^{\circ} 46^{\prime} \mathrm{S} 140^{\circ} 58^{\prime} \mathrm{E}, 15$ Apr 1987, P. Johnson. 1 오 $\mathrm{N}$ of Chinamans Well, Big Desert, 2 Mar 1982, A.J. Coventry. 1 juv, Grampians, Nov 1885. 1 ㅇ, $5.4 \mathrm{~km}$ E of Hattah, $34^{\circ} 47^{\prime} \mathrm{S} 142^{\circ} 20^{\prime} \mathrm{E}, 24$ Jan 1986, G. Milledge. $10^{\circ}, 15 \mathrm{~km} \mathrm{SSW}$ of Hattah, $34^{\circ} 54^{\prime} \mathrm{S} 142^{\circ} 15^{\prime} \mathrm{E}$, 24 Jan 1986, G. Milledge. $19,19.2 \mathrm{~km} \mathrm{SW}$ of Hattah, $34^{\circ} 54^{\prime} \mathrm{S} 142^{\circ} 09^{\prime} \mathrm{E}$, $21 \mathrm{Jan} 1987, \mathrm{G}$. Milledge. $19,20.8 \mathrm{~km}$ SE of Hattah, $34^{\circ} 52^{\prime} \mathrm{S} 142^{\circ} 28^{\prime} \mathrm{E}$, 25 Jan 1987, G. Milledge. $1 \delta^{\star}$, Inglewood. $1 \mathrm{~m}, 0.5 \mathrm{~km} \mathrm{~W}$ of Lake Hattah, 28 Jan 1986, G. Milledge. 1 \% , Lake Hattah, 18 Oct 1985, G. Milledge. 1 \% , Lake Hattah, 8 Apr 1982, G. Milledge. $10^{\star}$, Mallee District, 3 Mar 1914 , C. French. $19,12.8 \mathrm{~km} \mathrm{~N}$ of Millewa South Bore, $34^{\circ} 40^{\prime} \mathrm{S}$ $141^{\circ} 04^{\prime} \mathrm{E}, 27$ Mar 1986, G. Milledge. 1 ㅇ, $3.1 \mathrm{~km} \mathrm{~N}$ of Millewa South Bore, $34^{\circ} 45^{\prime} \mathrm{S} 141^{\circ} 04^{\prime} \mathrm{E}, 14 \mathrm{Nov} 1985$, G. Milledge. $19,0.6 \mathrm{~km} \mathrm{~N}$ of Millewa South Bore, $34^{\circ} 46^{\prime} \mathrm{S} 141^{\circ} 04^{\prime} \mathrm{E}, 21 \mathrm{Feb} 1986$, G. Milledge. $10^{\star}$, $7 \mathrm{~km} \mathrm{SSW}$ of Morkalla, 34 $26^{\prime} \mathrm{S} 141^{\circ} 08^{\prime} \mathrm{E}, 15$ Nov 1985, G. Milledge. $19,6 \mathrm{~km} \mathrm{SW}$ of Murray Valley Hwy \& Annuello Rd junction, $34^{\circ} 50^{\prime} \mathrm{S}$ $142^{\circ} 35^{\prime} \mathrm{E}, 10 \mathrm{Feb} 1986$, G. Milledge. $20^{\wedge}, 16.8 \mathrm{~km} \mathrm{SSW}$ of Murrayville, $35^{\circ} 25^{\prime} \mathrm{S} 141^{\circ} 10^{\prime} \mathrm{E}, 18 \mathrm{Feb} 1987$, G. Milledge. 2 웅 $16.8 \mathrm{~km} \mathrm{SSW}$ of Murrayville, $35^{\circ} 25^{\prime} \mathrm{S} 141^{\circ} 10^{\prime} \mathrm{E}, 23 \mathrm{Feb} 1987, \mathrm{G}$. Milledge. 1 ㅇ, $16.8 \mathrm{~km}$ SSW of Murrayville, $35^{\circ} 25^{\prime} \mathrm{S} 141^{\circ} 10^{\prime} \mathrm{E}, 19 \mathrm{Feb} 1986$, G. Milledge. 1 으, $7 \mathrm{~km} \mathrm{SW}$ of Nowingi, $34^{\circ} 39^{\prime} \mathrm{S} 142^{\circ} 16^{\prime} \mathrm{E}, 16$ Oct 1985 , G. Milledge. 1 , 1 juv, Ouyen, 26 Jun 1912, W.A. Hall. 1o, Ouyen, 26 Apr 1911, S.S. Scaree. $1 \hat{0}$, Round Swamp, Big Desert, 35 $42^{\prime}$ 'S $141^{\circ} 43^{\prime} \mathrm{E}, 28 \mathrm{Mar}$ 1985, G. Milledge. $10^{\dagger}, 6.9 \mathrm{~km} \mathrm{~N}$ of Round Swamp, Big Desert, $35^{\circ} 41^{\prime} \mathrm{S}$ $141^{\circ} 43^{\prime} \mathrm{E}, 28$ Mar 1983, G. Milledge. 3 \% , The Springs, Murrayville Track, Big Desert, 28 Mar 1985, G. Milledge. 2 ㅇ, Waithe Fauna Reserve, $19 \& 22$ May 1986, G. Milledge. 1 \% , 4 km N of Wedderburn, $36^{\circ} 23^{\prime} \mathrm{S}$ $143^{\circ} 37^{\prime}$ E, 18 Nov 1989, G. Milledge. 1 ơ, Woomelang, 4 Dec 1902, Mr Hill (all NMV).-WESTERN AUSTRALIA: 1 \% , Nedlands, Jan 1941, K.R. Norris. $1 \hat{0}$, Eyre Tower Microwave Station, $22 \mathrm{~km}$ ESE of Cocklebiddy, $32^{\circ} 08^{\prime} \mathrm{S} 126^{\circ} 17^{\prime} \mathrm{E}, 7$ Oct 1982 , D.C.F. Rentz. 1 juv, $23 \mathrm{~km}$ ESE of Cocklebiddy, $32^{\circ} 08^{\prime} \mathrm{S} 125^{\circ} 18^{\prime} \mathrm{E}, 25$ Oct 1977 , M.S. Upton \& J.E. Feehan. 10 , Cocklebiddy Repeater Stn., $36 \mathrm{~km} \mathrm{SW}$ of Caiguna, 3 Nov 1984, D.C.F. Rentz. $2 \hat{\delta}$, Lake Douglas, $12 \mathrm{~km} \mathrm{SW}$ of Kalgoorlie, 13 Jan 1989 , M.S. \& B.J. Moulds. 10 , Kununurra, 16-19 Sep 1979, L.P. Kelsey. 2 9, $13 \mathrm{~km}$ SSE of Dongara, $28^{\circ} 21^{\prime} \mathrm{S} 115^{\circ} 00^{\prime} \mathrm{E}, 12$ Sep 1981, D.C.F. Rentz. 1 \%, Cape Naturaliste Lighthouse, $33^{\circ} 32$ 'S $115^{\circ} 01^{\prime} \mathrm{E}, 15 \mathrm{Feb} 1980$, D.C.F. Rentz. 1 ㅇ, $19 \mathrm{~km} \mathrm{~S}$ of Menangina HS, $85 \mathrm{~km} \mathrm{E}$ of Menzies, $24 \mathrm{Feb}$ 1983, M.J. Whitten. $19,27 \mathrm{~km} \mathrm{~S}$ of Balladonia Motel, $32^{\circ} 35^{\prime} \mathrm{S} 123^{\circ} 36^{\prime} \mathrm{E}$, 13 Feb 1978, D.C.F. Rentz \& M.J.D. White. $19,31 \mathrm{~km} \mathrm{~S}$ of Balladonia Motel, 9 Feb 1980, D.C.F \& B.G.F. Rentz. $1 \delta^{\hat{\sigma}}, 36 \mathrm{~km}$ WNW of Balladonia Hotel, 5 Mar 1982, M.J.D. White. $10^{\hat{0}} 60 \mathrm{~km} \mathrm{SSW}$ of Norseman, $32^{\circ} 38^{\prime} \mathrm{S} 121^{\circ} 29^{\prime} \mathrm{E}, 17$ Nov 1969 , Key \& Upton. 1 웅, Cockleshell Gully, $19 \mathrm{~km}$ NNE of Jurien, $30^{\circ} 09^{\prime} \mathrm{S} 115^{\circ} 07^{\prime} \mathrm{E}, 25$ Oct 1984, D.C.F. Rentz. 1 ㅇ, Crawley, 15 Mar 1934, K.R. Norris. $20^{\uparrow}, 33$ km ENE of Perth, 30 Jan 1967, M.S. Upton. 1 juv, $37 \mathrm{~km} \mathrm{SW}$ of Mt. Ragged, $33^{\circ} 40^{\prime} S 123^{\circ} 11^{\prime} E, 2$ Nov 1977, M.S. Upton \& J.E. Feehan. $20^{\circ}, 5 \mathrm{~km} \mathrm{SW}$ of Mt. Ragged, 12 Nov 1969, Key \& Upton. 10, $20 \mathrm{~km}$ SSE of Yanchep, 9 Sep 1981, D.C.F. Rentz. 1 \&, 15 km WSW of Fraser Range HS, $32^{\circ} 04^{\prime}$ S $122^{\circ} 39^{\prime}$ E, 6 Sep 1981, D.C.F. Rentz. 1 ㅇ, 27 km W of Eneabba, $29^{\circ} 49^{\prime} \mathrm{S} 114^{\circ} 59^{\prime} \mathrm{E}, 9$ Sep 1981, D.C.F. Rentz. $10^{\dagger}$, Fitzgerald National Park, $12 \mathrm{~km} \mathrm{NE}$ of Hopetoun, 33 $51^{\circ} \mathrm{S} 120^{\circ} 09^{\prime} \mathrm{E}, 10 \mathrm{Feb} 1980$, D.C.F. \& B.G.F. Rentz (all ANIC). 10 , Junga Dam, $23 \mathrm{~km}$ ESE of 
Kalbarri, 6 Jan 1969, Kalbarri Survey. 1 đo, Miling, Jan 1976, T. Verbakel. $10^{\star}, 7.5 \mathrm{~km}$ E of Yuinmery HS, $28^{\circ} 34^{\prime} \mathrm{S} 119^{\circ} 01^{\prime} \mathrm{E}, 11-19 \mathrm{Feb} 1980$, T.F. Houston et al., 1 juv, Roebourne, 1922. 1 juv, Cunderdin, Jul-Aug 1913. 1 juv, Fitzgerald River Reserve, Jul 1970, A. Baynes. 1 juv, 13.6 km SSW of Mt Jackson, 30 $59^{\prime}$ S $119^{\circ} 07 \mathrm{E}, 5-11$ Sep 1979, T.F. Houston $e t$ al., 1 juv, Corrigin. 1 juv, $1.6 \mathrm{~km} \mathrm{~W}$ of Mundaring Weir, 6 Mar 1963, J.Dell. 1 juv, $30 \mathrm{~km} \mathrm{~N}$ of Bullfinch, 30 $0^{\circ} 59^{\prime} \mathrm{S} 119^{\circ} 07^{\prime} \mathrm{E}, 7$ Sep 1979, T.F. Houston et al., 1 juv, Kanowna, 30³6'S $121^{\circ} 36^{\prime} \mathrm{E}, 16$ Oct 1968, R.P. McMillan. 1 juv, Carollgouda Well, Kalbarri area, 30 Nov 1968, Hale School (all WAM).

Diagnosis. Can be distinguished from $T$. obesa by the facial shield being approximately as high as wide.

Description. Body (Figs. 26-27) rather large. Colour uniform green or bluish green. Head (Fig. 31) and frontal shield approximately as high as wide with ridge of frontal shield produced into prominent point at apex. Prothorax with fine scattered tubercles on dorsal surface, more so in female; lateral margin finely denticulate. Fore leg (Fig. 32) with inner face of coxa without markings, anterior margin with 9-11 small denticles; inner face of fore femur with large dark patch proximal to claw groove (not apparent in some specimens) and three small dark spots distal of claw groove; femora of mid and hind legs often orange red in proximal half. Wings of male longer than abdomen, those of female shorter than abdomen; ventral surface of costal area of tegmen dark bluish grey in anterior half; discoidal area completely opaque in female, only partly so in male; hind wing with costal and discoidal area yellowish green, anal area hyaline. Abdomen of female with posterior margin of fourth and particularly fifth sternite curved ventrally. Male genitalia (Fig. 33) with moderately elongate $a p r$, narrowed distally; $p a$ with anterior hook-like projection and posterior knob-like projection; distal projections of $d p r$ of moderate length, anterior one longer than posterior one.

Measurements (mm). Body length, ơ 53-75, 우 59-75. Pronotum length, ô 19-20, ㅇ 21-26. Pronotum width, $\hat{0}$ $5.5-6$, o 7-9. Fore coxa length, ô 12-15, o 15-19. Fore femur length, ô 13-16, $ᄋ$ 18-22. Hind femur length, $\hat{o}$ $14.5-15$, ㅇ 17-22. Hind tibia length, of 15-16, 우 17-23. Tegmen length, ơ 42-54, ㅇ 28-38.

Immature stages. First two instars dark coloured and antlike in behaviour and appearance. Ootheca squat, cream to sandy orange in colour. Appears to be mostly laid on the ground, usually attached to a piece of timber. The peculiar form of abdominal sternites 4-5 in the female may play a role in ootheca deposition.

Distribution and habits. Found across the arid regions of southern and central Australia (Fig. 46). Appears to be most commonly associated with mallee vegetation where the blue green body colour blends well with the leaves of certain mallee eucalypts. I have observed numerous individuals of this species, in nature and captivity, and never seen the cryptic behaviour displayed by members of the genus Sphodropoda. Adult females are commonly caught in pitfall traps, probably in the process of seeking oviposition sites. This would also suggest they are not capable of effective flight.

Remarks. The original description appears to be based on one specimen although this is not specified. One of the two female syntypes is labelled type, the other cotype. These are printed labels and there is no indication that they were placed there by the author. Therefore, I have decided not to designate a lectotype. A syntype specimen is illustrated by Sjöstedt (1930, plate 8, fig. 1)

\section{Zopheromantis}

Zopheromantis Tindale, 1924: 550. Type species Zopheromantis trimaculata Tindale, by monotypy.

Diagnosis. Head approximately as high as wide, frontal shield without pronounced tooth at apex; preacetabular spine strong; ventral face of fore femur tuberculate, especially toward outer margin; male macropterous, female brachypterous, ventral face of costal area of tegmen red, mid and hind legs normal. Can be distinguished from Trachymantis by the absence of the apical tooth on the frontal shield and from Sphodropoda by the length of the mid and hind legs, the femur of the hind leg being distinctly longer than half the length of the abdomen.

Description. Body small to medium in size, male macropterous, female brachypterous. Head about as wide as high, not significantly compressed anteroposteriorly, apical margin gently arched; eyes rounded, not particularly prominent; frontal shield slightly wider than high, flat, with distinct ridge laterally and apically, forming blunt point at apex. Pronotum moderately elongate, rather slender, supracoxal expansion distinct, dorsally sparsely granulate in prozone, metazone almost smooth, margins finely denticulate in female largely entire in male, ventral surface with preacetabular spine prominent. Fore coxa as long as metazone of pronotum, with or without markings, a number denticles on anterior margin. Fore femur finely tuberculate on ventral surface, particularly toward outer margin; with four discoidal spines, relative length longest to shortest 3214; with four outer and 16-17 inner spines, claw groove situated at about a third the total distance from base. Tegmen with costal area opaque, red beneath; discoidal area entirely opaque to mostly hyaline. Hind wing with costal and discoidal area pigmented, anal area largely hyaline. Mid and hind legs normal, hind femur more than half the length of abdomen. Abdomen moderately elongate, cerci short, slender and cylindrical. Male genitalia with $d p r$ bifurcate.

\section{Zopheromantis loripes (Tindale, 1923) n.comb.}

Figs. 34-35, 39-41, 47

Sphodropoda loripes Tindale, 1923: 446.

Zopheromantis trimaculata Tindale, 1924: 551, new synonym. Hierodula trimaculata Beier, 1935: 82.

Material examined. Lectotype male (here designated) of Sphodropoda loripes, Cunnamulla, Queensland, H. Hardcastle, I-14071 (SAM). Holotype female of Zopheromantis trimaculata, Teetulpa, South Australia, Jan. 1904, G. Farrand, I-14590 (SAM).—QUEENSLAND: 10, Coopers Creek, $10.7 \mathrm{~km} \mathrm{NE}$ of Windorah, $25^{\circ} 22^{\prime} 18^{\prime \prime S} 142^{\circ} 44^{\prime} 41^{\prime \prime E}, 4$ Apr 1991, G.V. Maynard \& G. Davis. 10, 33 km W of Quilpie, 16 Mar

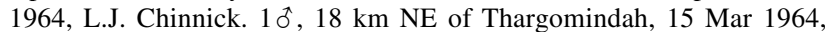
L.J. Chinnick. 10, $23 \mathrm{~km} \mathrm{SW}$ of Toompine, 10 Apr 1970, R.C. Lewis (all ANIC). 1 \% , Augathella, 25 48'S 146 $25^{\circ} \mathrm{E}, 18$ Jan 1993, G. Milledge (NMV).-NEW SOUTH WALES: 30, $18 \mathrm{~km}$ WNW of Bourke, 9 Feb 1972, R.C. Lewis. 5 \&, $6 \mathrm{~km} \mathrm{~W}$ of Cobar, 23 Mar 1972, White \& Jaworska. 1 \&, $7 \mathrm{~km} \mathrm{~W}$ of Cobar, 20 Feb 1963, L.J. Chinnick. $1 \delta^{\text {}, ~} 2$ juv, $7 \mathrm{~km} \mathrm{~W}$ of Cobar, 1 Feb 1964, M.J.D. White. 1 , 15 km SW of Enngonia, 14 Jan 1965, M.J.D. White. 10 , $37 \mathrm{~km} \mathrm{SE}$ of Wanaaring, 10 Feb 1972, R.C. Lewis. $1 \delta, 1 \mathrm{~km} \mathrm{~W}$ of Warri gate, 11 Feb 1972, R.C. Lewis. 1 juv, 17 km SE of Wilcannia, 31 Jan 1964, M.J.D. White (all ANIC).-NORTHERN TERRITORY: $2 \hat{\sigma}, 37 \mathrm{~km} \mathrm{~S}$ of Alice Springs, 15 Feb 1966, Britton, Upton \& McInnes. 10, $103 \mathrm{~km}$ NNW of Alice Springs, 12 Feb 1966, Britton, 

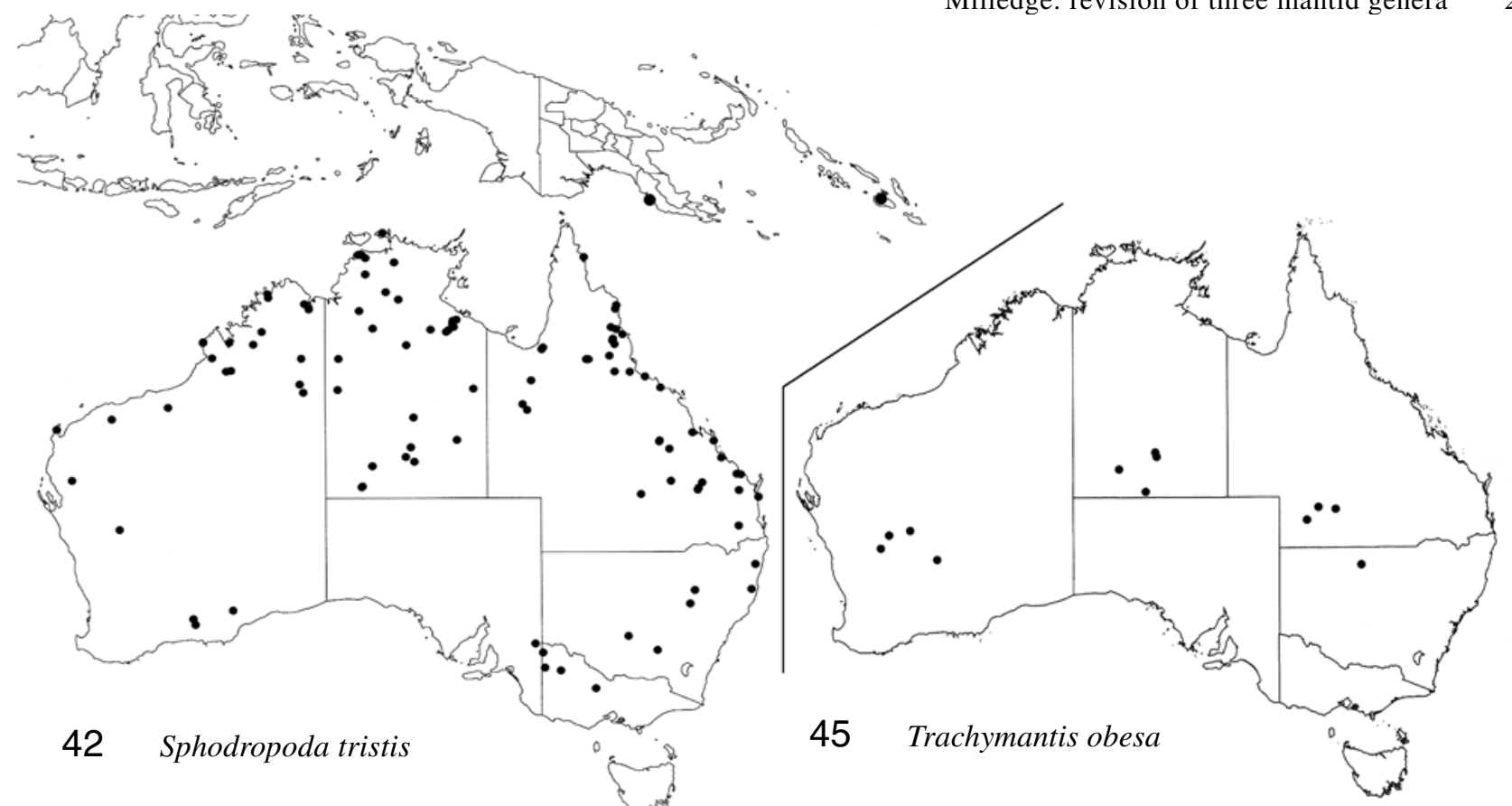

$42 \quad$ Sphodropoda tristis
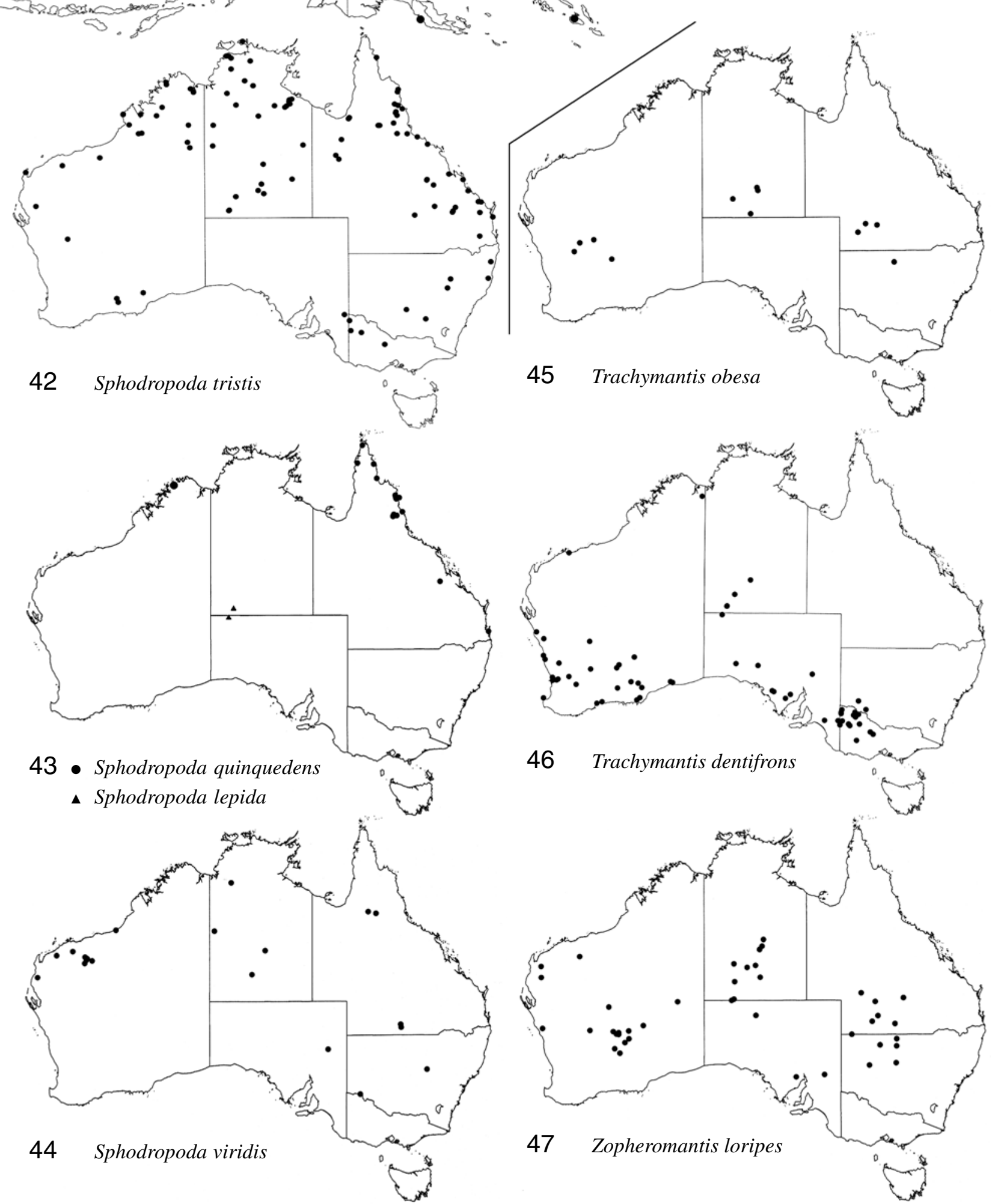

Figs. 42-47. Distributions of Australian mantids: (42) Sphodropoda tristis; (43) • S. quinquedens, ^ S. lepida; (44) S. viridis; (45) Trachymantis obesa; (46) T. dentifrons; (47) Zopheromantis loripes.

Upton \& McInnes. 1ठิ, Barrow Creek Tel.Sta., 20 Mar 1955, K.H.L. Key. 10 , 3 km S of Barrow Creek, 13 Feb 1966, Britton, Upton \& McInnes. 1 ㅇ, $25 \mathrm{~km} \mathrm{NW}$ of Mount Wedge HS, 10 Apr 1963, L.J. Chinnick. 1 ऽิ, $5 \mathrm{~km}$ W of Mulga Park HS, 24 Mar 1963, L.J. Chinnick. $1 \delta^{\circ}, 26 \mathrm{~km}$ WSW of Mulga Park HS, $26^{\circ} 00^{\prime} \mathrm{S} 131^{\circ} 25^{\prime} \mathrm{E}, 18$ Jan 1982 , D.C.F., B.G.F. Rentz. 1 ơ, 25 km NE of Narwietooma HS, 9 Apr 1963, L.J. Chinnick \& R. Honeycutt. 1 ô, Taylors Creek, $47 \mathrm{~km} \mathrm{~N}$ of Barrow
Creek township, 22 Jan 1984, M.S. \& B.J. Moulds. $1 \widehat{o}^{\star}$, Wauchope, 21 Mar 1955, K.H.L. Key (all ANIC). $2 \hat{\jmath}$, Kathleen Creek, Watarrka National Park, Horn Centenary Expedition, 2420'38"S 131 ${ }^{\circ} 40^{\prime} 54^{\prime \prime E}$, 14 Mar 1995, G. Milledge (both NMV).-SOUTH Australia: $19,7 \mathrm{~km}$

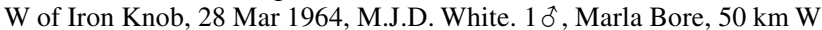
of Welbourne Hill, 23 Mar 1963, L.J. Chinnick (both ANIC).-WESTERN AUSTRALIA: $20^{\dagger}, 23 \mathrm{~km}$ WSW of Barradale, $22^{\circ} 56^{\prime} \mathrm{S} 114^{\circ} 45^{\prime} \mathrm{E}, 30 \mathrm{Mar}$ 
1971, Upton \& Mitchell. 1 ㅇ, Canegrass, 8 Feb 1981, M.J.D. White. $19,5 \mathrm{~km}$ NE of Kanowana ruins, near Broad Arrow, 18 Feb 1981, M.J.D. White. $10,5 \mathrm{~km} \mathrm{NE}$ of Kanowana ruins, near Broad Arrow, $24 \mathrm{Feb}$ 1981, M.J.D. White. 1 , Malcolm, 21 Feb 1979, M.J.D. White. 19 , 1 $\mathrm{km} \mathrm{S}$ of Malcolm, $28^{\circ} 47^{\prime} \mathrm{S} 121^{\circ} 31^{\prime} \mathrm{E}, 19 \mathrm{Feb}$ 1978, D.C.F. Rentz \& M.J.D. White. 10 , $6 \mathrm{~km} \mathrm{SE}$ of Mt. Boyce, near Yerilla HS, SE of Leonora, 15 Feb 1983, M.J.D. White. 2 juv, Mt. Leonora, near Leonora, 13 Feb 1981, M.J.D. White. 1 q , Mt. Leonora, near Leonora, 10 Feb 1983, M.J.D. White. 1 , $3 \mathrm{~km}$ NNE of Mt. Ross, NW of Leonora, $28^{\circ} 41^{\prime} \mathrm{S} 121^{\circ} 03^{\prime} \mathrm{E}$, 18 Feb 1978, D.C.F. Rentz \& M.J.D. White. 1 ô, New Yamarna HS, S of Minnie Creek, near Virginia Range, 31 Jan 1967, M.J.D. White. 1 , 43 km NW of Wittenoom, 22 Apr 1963, L.J. Chinnick (all ANIC). 19 , Middalya, 4 Feb 1902, T. Watt (NMV). 20 , Kathleen Valley, 1963, T. Moriarty. $1 \hat{\delta}$, Lake Violet. $1 \hat{\delta}$, Laverton. $1 \hat{\delta}, 2.5 \mathrm{~km} \mathrm{~N}$ of Mt. Linden, $29^{\circ} 19^{\prime} \mathrm{S} 122^{\circ} 25^{\prime} \mathrm{E}, 17-23$ Mar 1979, T.F. Houston. $10^{\circ}, 1$ 으, Nolba, $28^{\circ} 22^{\prime} \mathrm{S} 114^{\circ} 52^{\prime} \mathrm{E} .10^{\dagger}$, Warburton Ranges, 25 Mar 1963, H. De Graff. $10^{\circ}, 7.5 \mathrm{~km}$ E of Yuinmery HS, $28^{\circ} 34^{\prime} \mathrm{S} 119^{\circ} 01^{\prime} \mathrm{E}, 11-19 \mathrm{Feb} 1980$, T.F. Houston. $10^{\top}, 9 \mathrm{~km}$ SE of Yuinmery HS, $28^{\circ} 34^{\prime} \mathrm{S} 119^{\circ} 01^{\prime} \mathrm{E}, 25 \mathrm{Mar} 1979$, T.F. Houston (all WAM).

Description. Body (Figs. 34-35) size varies from small to medium. Body colour uniform green or bluish green. Head (Fig. 39) approximately as high as wide; frontal shield slightly wider than high, more so in male. Fore leg (Fig. 40) with inner face of coxa without markings or with one to three dark spots, anterior margin with 7-8 small tubercles; inner face of femur without markings; inner face of tarsal segments dark at distal end. Wings of male longer than abdomen, those of female slightly shorter than abdomen; ventral surface of costal area of tegmen red with narrow pale band on anterior margin; discoidal area completely opaque in female, only partly so in male; hind wing with costal and discoidal area yellowish green, anal area hyaline. Male genitalia (Fig. 41) with short, stout $a p r, p a$ with single, blunt pointed anterolateral projection, dorsal edge slightly folded; distal projections of $d p r$ moderately elongate and narrowed.

Measurements (mm). Body length, o 37-50, ㅇ 39-58. Head width, ô 6-7, ㅇ 7-8. Head depth, ô 3.5-5, ㅇ 4.56.5. Pronotum length, o $11-13$, o $15-22$. Pronotum width, oิ 3-4.5, ㅇ 4-6. Fore coxa length, ơ 7-9, ㅇ 11-14. Fore femur length, of 8.5-12, ㅇ 12-16. Hind femur length, o 8.5-12, ㅇ 12-18. Hind tibia length, ơ 9.5-12, 우 13-19. Tegmen length, ơ 27-35, ㅇ 19-29.

Immature stages. Juveniles similar in appearance to adults, ootheca unknown.

Distribution and habits. Found in the arid regions of the continent (Fig. 47). The few specimens of this species that I have collected have been found in Acacia shrubs. None displayed the cryptic behaviour associated with Sphodropoda.

Remarks. The female syntype of Sphodropoda loripes described by Tindale is, in fact, a female of Sphodropoda viridis. Therefore I have designated the male syntype as the lectotype.

ACKNOWLEDGMENTS. I would like to thank M. Moulds (AM), D. Rentz (ANIC), J. Marshall (BMNH), K. Johanson (NHRM), K. Walker (NMV), J. Forrest (SAM), T. Houston (WAM) and M. Ohl (ZMHU) for the loan of specimens. S. Lindsay (AM) prepared the S.E.M. images.

\section{References}

Balderson, J., 1984. Catalogue of Australian Mantodea. CSIRO Technical Paper no. 23.

Balderson, J., D.C.F. Rentz \& A.M.E. Roach, 1998. Mantodea. In Zoological Catalogue of Australia, Archaeognatha, Zygentoma, Blattodea, Isoptera, Mantodea, Dermaptera, Phasmatodea, Embioptera, Zoraptera, ed. W.W.K. Houston \& A. Wells, pp. 251-277, vol. 23. Melbourne: CSIRO Publishing, Australia.

Beier, M., 1935. Mantodea: Fam. Mantidae: Subfam. Mantinae. Genera Insectorum 203: 1-146.

Beier, M., 1964. Blattopteroidea: Mantodea. Bronns Klassen und Ordungen des Tierreichs (5) (3) 6: 849-970. Leipzig: Akademische Verlagsgesellschaft Geest \& Portig K.-G.

Beier, M., 1965. Die Mantodeen Neu-Guineas. Pacific Insects 7 (3): 473-502.

Chapman, R.C., \& J. Balderson, 1984. Ovipositional behaviour of Sphodropoda tristis Saussure (Mantodea: Mantidae). Australian Entomological Magazine 11(1): 5-7.

Giglio-Tos, E., 1911. Mantidi Esotici. II. Le Polispilote. Societa entomologica Italiana, Bollettino 42: 3-38.

Giglio-Tos, E., 1917. Mantidi Esotici. Generi e specie nouve. Societa entomologica Italiana, Bollettino 48: 43-108.

Heath, G.L., \& G. Cowgill, 1989. Rearing and Studying the Praying Mantids. Leaflet no. 36, Amateur Entomologists' Society, London.

Hevers, J., \& H. Liske, 1991. Lauernde Gefahr. Das Leben der Gottesanbeterinnen. Braunschweig: Staatliches Naturhistorisches Museum.

Kirby, W.F., 1904. A Synonymic Catalogue of Orthoptera. Volume 1. London: British Museum (Natural History).

Macleay, W.S., 1826. In Narrative of a Survey of Inter-tropical and Western Coasts of Australia Performed between the Years 1818 and 1822 by Captain Phillip P. King, vol. 2, by P.P. King. London: John Murray.

Milledge, G., 1990. Revision of the genus Nesoxypilus (Mantodea: Amorphoscelidae: Paraoxypilinae). Memoirs of the Museum of Victoria 50(2): 347-355.

Milledge, G., 1997. Revision of the tribe Archimantini (Mantodea: Mantidae: Mantinae). Memoirs of the Museum of Victoria 56(1): 1-63.

Preston-Mafham, K., 1990. Grasshoppers and Mantids of the World. London: Blanford.

Saussure, H., 1871. Mélanges Orthoptérologiques. Fascicule 3. Memoires de la Societé de Physique et d'Histoire naturelle de Geneve 21: 1-214.

Sjöstedt, Y., 1918. Results of Dr E. Mjöberg's Swedish scientific expeditions to Australia 1910-1913. 17. Mantidae and Phasmidae. Arkiv fur Zoologi 11(19): 1-60.

Sjöstedt, Y., 1930. Orthopterentypen im Naturhistorischen Reichsmuseum zu Stockholm. I. Mantidae. Arkiv fur Zoologi 21A(32): 1-43.

Stål, C., 1871. Orthoptera quaedam africana. Öfversigt af Konglia Vetenskaps-Akademiens förhandlingar 3: 375-401.

Stål, C., 1877. Systema Mantodeorum. Bihang till Konglia Svenska Vetenskaps-Akademiens Handlingar 4(10): 1-91.

Tindale, N., 1923. Review of Australian Mantidae. Records of the South Australian Museum 2: 425-457.

Tindale, N., 1924. Review of Australian Mantidae. Part 2. Records of the South Australian Museum 2: 547-552.

Westwood, J.O., 1889. Revisio Insectorum Familie Mantidarum, Speciebus Novis aut Minus Cognitis Descriptis et Delineatis. London: Gurney and Jackson.

Manuscript received 19 August 2003, revised 4 March 2004 and accepted 7 April 2004.

Associate Editor: M.S. Moulds. 